\title{
PUBLIC PERCEPTIONS OF INDUSTRIAL RISKS: THE CONTEXT OF PUBLIC ATTITUDES TOWARD RADIOACTIVF WASTE
}

\section{Timothy C. Earle}

PRINCIPAL INVESTIGATOR

S. M. Nealey

JUNE 1981

Prepared for the Waste Management Systems Studies Program of the Pacific Northwest Laboratory of the U.S. Department of Energy under contract DE-AC06-76RLO-1830

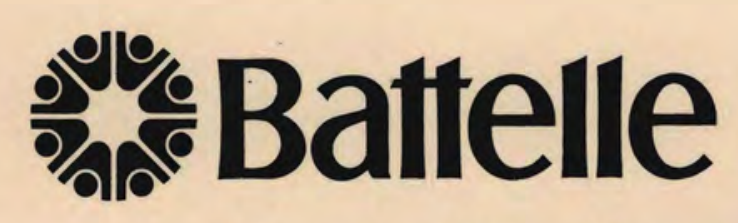

Human Affairs Research Centers

4000 N.E. 41st Street $\bullet$ Seattle, Washington 98105 


\section{Legal Notice}

This report was prepared by Battelle as an account of sponsored research activities. Neither Sponsor nor Battelle nor any person acting on behalf of either: (a) Makes any warranty or representation, express or implied, with respect to the accuracy, completeness, or usefulness of the information contained in this report or that the use of any information, apparatus, process, or composition disclosed in this report may not infringe privately owned rights; or (b) Assumes any liabilities with respect to the use of, or for damages resulting from the use of, any information, apparatus, process, or composition disclosed in this report. 
PUBLIC PERCEPTIONS OF INDUSTRIAL RISKS: THE CONTEXT OF PUBLIC ATTITUDES TOWARD RADIOACTIVE WASTE

Timothy C. Earle

Principal Investigator

S. M. Nealey

June, 1981

Prepared for the Waste Management Systems Studies Program of the Pacific Northwest Laboratory of the U.S. Department of Energy under contract DE-ACO6-76RLO-1830

Battelle Memorial Institute Human Affairs Research Centers Social Change Study Center Energy and Environment Program Seattle, Washington 98105 
The generation of knowledge regarding public risk perception in general, and perception of risks associated with nuclear power and radioactive waste management in particular, requires the development and use of appropriate survey methodologies. One of the fundamental limitations of many studies of public risk perception is the assumption on the part of the investigators of similarity between themselves and their respondents. In such studies respondents are required to deal with problems of interest to and structured by the investigators. If a particular study includes heterogeneous groups, many of the respondents could differ significantly from the investigators. These respondents could find themselves being asked to provide opinions and judgments about issues and problems they had never before considered, which could produce misleading results. An attempt was made in the present study to deal with this methodological issue through the use of "free response" survey items, which allow respondents to structure their responses in ways that make sense to them.

Respondents were selected according to a purposive sampling strategy, with emphasis both on sampling the general public in specific geographical locations and on sampling the memberships of established groups. The study thus was not designed to lend itself to making probability statements about particular populations, especially that of the United States as a whole; instead, it was designed to explore comparisons among established groups. Six groups were selected on the 
basis of the interests of their members in risks associated with industrial facilities. The six included: 1) Nuclear Engineers (a national organization of nuclear engineers), 2) Chemical Engineers (a national organization of chemical engineers), 3) Science Writers (a national organization of science writers), 4) Environmentalists (one West Coast, one East Coast, and one national environmental group), 5) Hazardous Facility Communities (residents of six communities in which potentially hazardous industrial facilities are located), and 6) General Communities (residents of six comunities chosen without regard to hazardous industrial facilities). Questionnaires were delivered to potential respondents using standard survey mailing procedures; a total of 819 respondents provided usable data.

The data presented in this report are derived from eight questionnaire items, the first four of which referred to "the closest hazardous facility that concerns you." The first item in this series asked respondents how near it was to where they lived. No constraints were imposed on what constituted a hazardous facility. Almost half (49.5\%) of the respondents identified a hazardous facility within ten miles; $14 \%$ identified no hazardous facility within fifty miles. As expected, the Hazardous Facilities Communities group reported hazardous facilities wach closer to them than did the other groups.

The second item asked what sort of hazardous facility the closest one was. A Nuclear Power Plant was the most frequently identified facility ( $34 \%$ of all respondents); this was true for all groups except the Nuclear Engineers. Respondents who named facilities in the categories of Chemical Production, Coal-fired Power Plant and General Heavy Industry 
tended to report smaller distances than those who mentioned a Nuclear Power Plant or a Nuclear Waste Disposal Facility. Residents of Hazardous Facilites Communities reported living closer than other groups to the types of facilities that were, in fact, closer to their homes.

The third item asked what types of risk were associated with the facility. The two most frequently nominated risks overall were Pollution (28.6\%) and Leak of Radioactive Materials (22.8\%); types of risk varied greatly with types of facility. The most frequently mentioned exposure path was a Leak of Radioactive Material from a Nuclear Power Plant $(20.0 \%$ of all combinations). Types of risk mentioned were moderately related to (i.e., differed as a function of) respondent groups.

The fourth and final item in this series asked what persons would be placed at risk. The data showed a strong contrast between Nuclear Power Plant (associated to a greater extent with pervasive risks, including risks to future generations) and the other hazardous facilities (associated to a greater extent with risks affecting specific groups of particularly vulnerable persons). Relatively little mention was given to concerns for members of future generations; categories referring in any way to future generations accounted for only $10.1 \%$ of the total responses.

Items five and six of the task referred to a Toxic Chemical Disposal Facility, and items seven and eight referred to a Nuclear Waste Disposal Facility. For each of these facilities, respondents were first asked what types of risk were associated with such a facility and, second, what persons were affected by the risks. Respondents produced a strong and clear contrast between the two facilities: a Toxic Chemical Disposal Eacility was seen as being more closely associated with pollution 
affecting the contemporary public, while a Nuclear Waste Disposal Facility was seen as being more closely associated with leaks of toxic materials affecting everyone, including future generations, the contemporary public and workers at the facility.

Strong and consistent differences among groups of respondents were found. Those respondents who were either physically closer or professionally identified with hazardous facilities (Hazardous Facility Communities, Chemical and Nuclear Engineers) were distinguished from the others by lower levels of concern about adverse effects, particularly health effects. This was, however, coupled with higher levels of concern for effects to specific groups of living persons, particularly workers at hazardous facilites. In contrast, those respondents who were not closely related to hazardous facilities (General Cormunities, Environmentalists and Science Writers) were distinguished by higher levels of concern about adverse effects, particularly health effects, together with higher levels of concern for effects to everyone, including the contemporary public and future generations.

The methodological implications of the free-response technique were discussed in relation to results from two companion studies (Earle, et al., 1981; Lindell and Earle, 1981) that relied upon fixed response formats. Stated briefly, the data from Earle, et al., suggested that occupational risk was less important than the other two categories and that long term public risk was approximately equal in importance to short term public risk. In contrast, one would infer from the present study that short term public risk is most important, occupational risk is mext in importance and long term public risk is relatively unimportant. 
Data from Liadell and Earle showed that zespondents did not distinguish between a nuclear waste disposal facility and 3 toxic chemical disposai facility in their ratings on thirteen risk characteristies scales adopted from slovic et al. (1980). Free response data from the present study produced significant differences in risk perceptions. These were interprated as evidence in support of the need to appropriately utilize each of the two approaches to the study of risk perception. Free and fixed response formats should be used in conjunction with one another, with free rasponse items being used earlier in the exploration of a content area and fixed response items being used later. The nascent state of our present knowledge of public risk perception, particulariy with regard to nuclear power and zadioactive waste managemenc, requires the creation and use of methods of study that allow zespondents to express themselvas relatively freely, relatively unaffected by investigators' preconceptions. 
TABLE OF CONEITS

EXECUTIVE SLRARY. . . . . . . . . . . . . . . . . . i. TABLE OE CONZNTS. . . . . . . . . . . . . . . . . . . . vi. IIST OE TABLES . . . . . . . . . . . . . . . . . . .VII. INTRODUCTION ......................... ! RESTONDENSS. . . . . . . . . . . . . . . . . . . . 4 Sampling . . . . . . . . . . . . . . . . . . . . 4 Questionnaire Mailing Proceduzes . . . . . . . . . . . . . i Response Rates... . . . . . . . . . . . . . . . . . 9 RESULTS. . . . . . . . . . . . . . . . . . . . 14 DISCUSSION . . . . . . . . . . . . . . . . . . . . . . . . . REFEREYCES . . . . . . . . . . . . . . . . . . . . 65 DISTRIBUTION . . . . . . . . . . . . . . . . . . . . . . 
Table i. Response Rates Sor All Groups . . . . . . . . . . . 10

Table 2. Sumary of Demograpiia Compariscrs Among Respondent Groups . . . . . . . . . . . . . . . 13

Table 3. Cludative Rercentage os Respondents who Indicated the Existence of Hazarious Eacility Year Theiz Residence, by Jiskance. . . . . . . . . . . . . 15

Tajle 4. Group Marikings for gizs V Vie Distance Cazegories. . . . I

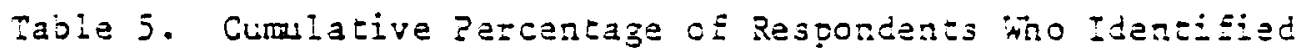
a Given Hazardous Eacilizy, by Distance... . . . . . . I?

Table 5. Hazardous Facility Rankings for Eizst Five Distance Categozies. . . . . . . . . . . . . . 2 2 :

Tabie 7. Closest Hazazdous Eacility, By Group. . . . . . . . . 22

Table 8. Type of Risk Associated with the Ciosest Hazardous Faciliey, 3y Facilizy. . . . . . . . . . . . 25

Tajle 9. Type of Risk Associated with the Closest Hazardous Zacility, By Group. . . . . . . . . . . . . 29

Tajle 10. Zersons Placed at Risk by the Ciosest Nazazdous Eacility. . . . . . . . . . . . . . 32

Table 11. The Six More Erequently Used Risk Cazagozias, by the Six More Frequenty Selacred Fazardous Facilizies... . . 33 
IIST OE TABLES (CORE.)

Page

Tajle 12. Percentaze of Respondents ino Ijentified a Given Caregory oE ?ersons as $3 e i r g$ Placed at

Risk by Closest Hazardous Facility, 3y Group. . . . . . . . 36

Table 13. Pazcencaze os Respondents tho Identisied a Given Type of Risk as Being Associazad with a Toric

Chemical Disposal Eacilizy, 3y Group. . . . . . . . . . 39

Tajle 14. Zercentaze of Respondents who Identified a Given

Type of Risik as Being tssociated wish a Toxic

Chemical Disposai Eacilizy, 3y Group. . . . . . . . . . 41

Tajle 15. Percentage oE Respondents ino Identified a Given

Type of Risk as Bei.zg Associaled with a kucleaz rasta

Disposal Eacility, By Group. . . . . . . . . . . . . . 43

Table 16. Rercentage of Respondents iño Identified a Giren

Category of Zersons as 3eing a: Risk Fco a iuclea=

Naste Disposal Jacilisy, 3y Group . . . . . . . . . . 4 4́

mable 17. Categories of Jypes of Risik tial Received Ei the=

Reiagively figh or low Usé, Jy Facility . . . . . . . . 53

Table 13. Categories of Persons Placed at Risk That Received

Either Relatively Hijt or Lod Use, 3y Facility. . . . . . 54 


\section{INTRODUCTION}

In their recent comprehensive survey of approaches to acceptable risk, Fischoff, Lichtenstein, Slovic, Derby \& Keeney (1980) provide this sumary of the state of knowledge regarding risk perception:

The way people perceive and respond to risks is central to acceptable risk decisions. Our present understanding of these processes is based on a small body of psychological work, using techniques of varying sophistication, and a large body of speculation by experts. [p.281]

The development of knowledge about public risk perception has been hampered by the use of inappropriate methods which assumed that the public was homogeneous and that it perceived risks in ways basically similar to those used by experts. Thus, survey researchers might require a public sample to produce the probabilities for a set of pre-defined events. The public sample, however, may seldom use probabilities in their everyday lives and they may never have considered many of the events presented to them.

One way to deal with these problems in the study of public risk perception is to present the public sample with "open-ended" or "free response" items which allow respondents to generate their own response alternatives, including that of giving no response at all (Selltiz, Wrightsman \& Cook, 1976, pp. 312-317). Such an approach was adopted here. A relatively unstructured approach to the study of public risk perception is appropriate given the current state of our knowledge. Unstructured items allow respondents to speak more directly to us than is the case in typical closed format survey items. Given the relatively 
unfiltered information the unstructured items provide, we will in followup surveys be able to more intelligently and fruitfully study selected aspects of public risk perception.

The utility of the free response approach used here can best be appreciated in contrast with studies investigating similar subject matrer but using highly structured response formats. A companion study to the present one offers just such a contrast (Earle, Lindell and Rankin, 1981). In that study, respondents judged the acceptability of alternative radioactive waste policies based on three factors, Short-term public risk, Long-term public risk and Occupational risk. Respondents thus were forced to make their judgments within a specified structure, and those judgments implied a certain relative weighting of the factors on which they were based. Implications about the relative importance that respondents placed on those same three risk categories can also be drawn from the results of the present free response items: the results of two companion studies will be contrasted with those of the present study in the discussion section of this report, and an argument will be made for the appropriate use of both free response and fixed response approaches to the study of risk perception (Lazarsfeld, 1944).

The general class of hazard investigated here included all hazardous industrial facilities. The free response survey method was used to study public perception of: a) the closeness of the nearest hazardous industrial facility (as estimated by the respondent), b) the sort of facility it is, c) the sorts of risk associated with it, and d) the persons placed at risk by it. Respondents also identified the risks of, 
and the persons placed at Iisk by, both a toxic chemical disposal

facility and a nuclear waste disposal facility. Results of this study

thus can inform us of the unprompted concerns of the public regarding a wide variety of industrial facilities. 


\section{RESPONDENTS}

Sampling

A purposive or "judgmental" sampling strategy (Babbie, 1973:106-108) was used in the present study. Purposive sampling, also known as "theoretical sampling" (Glaser \& Strauss, 1968:41-62), "scope sampling" (Willer, 1967:97-115) and "sampling of publics" (Blumer, 1948:542-549), is characterized by the sampling of the memberships of established groups. The selection of the established groups is guided by the research questions being studied: those groups are selected which would most efficiently provide the information required. Purposive sampling is far more efficient than probability sampling, which involves drawing a well-defined sample from a well-defined population. The degree to which a sample is representative of a population is statistically assured with probability sampling but not with purposive sampling. Since it is not a purpose of the present study to make probability statements about particular populations, the assured representativeness of population sampling is not required. This study is designed to explore comparisons among established groups, and purposive sampling allows those comparisons to be made efficiently.

Groups of potential respondents were selected on the basis of the interests of their membership in risks associated witi industrial facilities. Six groups were selected:

1. Nuclear Engineers: a national organization of nuclear engineers.

2. Chemical Engineers: a national organization of chemical engineers. 

3. Science Writers: a national organization of science writers.
4. Environmentalists: two regional (West coast and East coast) environmental groups and one national environmental group.

5. Hazardous Facility Communities: residents of six communities in which potentially hazardous industrial facilities are located.

5. General Communities: residents of six communities chosen without regard to hazardous industrial facilities.

Groups 1, 2, 3 and 4 include established groups. Individual respondents within each of these groups were randomly selected from membership 1ists. Groups 5 and 6 consist of nominal groups, formed only on the basis of geographical proximity. Al though the residents of the various communities are treated in subsequent data analyses as though they were members of established groups, there is no intent in this study to make statements about specific communities. What is intended are comparisons between the group of respondents living in Hazardous Facility Communities and the group of respondents living in General Communities, as well as comparisons among these two groups and the other four groups of respondents.

The six communities in the Hazardous Facility Communities group were selected on the basis of geographical diversity and type of hazardous facility:

1. Red Wing, Minnesota (nuclear power plant)

2. Waterford, Connecticut (nuclear power plant) 
3. Everett, Massachusetts (1iquified natural gas terminal)

4. Savannah, Georgia (liquified natural gas terminal)

5. Forsyth/Colstrip, Montana (coal-fired power plant)

6. Pueblo, Colorado (coal-fired power plant)

It should be noted that the hazardous facilities identified above are not necessarily the only potentially hazardous industrial facilities in each of the commities (Pueblo, for example, also contains a large steel mill). Also, an attempt was made to select communities in which the residents would likely be aware of the existence of a hazardous facility in their town. Thus, the Hazardous Facility Communities tend to be smaller than the General Commities.

Selection of the six commuties in the General Communities group was based on geographical diversity and size. The six geographic regions in the United States used by Cambridge Reports (1975; see Melber, et al., 1979) were adopted in this study; one community was selected from each region:

1. San Francisco (Pacific region)

2. Houston (Central region)

3. Chicago (Midlands region)

4. Detroit (Industrial region)

5. Boston (Northeast region)

6. Atlanta (South region)

Each of the six General Communities is one of the major cities in its geographic region. Large cities were selected on the grounds that a given individual in a large city would be less likely to live close to and be aware of a specific hazardous industrial facility than would a 
resident of a smaller community in which a major industrial facility is known to exist. Compare, for example, a resident of San Francisco and a resident of Red Wing. What industry there is in San Francisco is unlikely to intrude on the 1 ife of the average resident; the typical resident of Red Wing, on the other hand, is highly likely to be aware of the nuclear power plant located there. This contrast is based on the general notion that the large numbers of people, the extensive residential areas and the great variety and complexity of the surrounding environment all work to make it less likely that residents in the relatively large General Communities will live close to and be aware of a particular hazardous industrial facility than would residents in the relatively small Hazardous Facility Commities. For both the Hazardous Facility Communities and the General Commities, individual residents were randomly selected from the local telephone directories.

\section{Questionnaire Mailing Procedures}

The questionnaire was delivered to all respondents through the use of a slight variation of a standard mailing procedure (Dillman, 1978). Since the ratio of returned questionnaires to those mailed tends to be negatively affected by questionnaire length exceeding 11 pages (Dillman, 1978:54-57), the material to be covered was divided into two questionnaires rather than one. Questionnaire 非 was 10 pages in length, contained seven sections and was mailed to $50 \%$ of the potential respondents in each of the six groups. Questionnaire 非 was twelve pages in length, contained seven sections and was mailed to the remaining $50 \%$ of the potential respondents. The seven sections in each of the two questionnaires consisted of 2 sets: a) three tasks common to both 
questionnaires; b) four sections unique to each questionnaire. Due to this arrangement of tasks, there are three distinct sets of respondents:

a) Set 非 1 , those who responded to the tasks unique to Questionnaire 非 1 ;

b) Set $k_{2}$, those who responded to the tasks unique to Questionnaire $k^{2}$;

and c) Set 非, those who responded to the tasks common to both

questionnaires (i.e., the total set of respondents). These three sets of respondents are described in a later section of this report.

The questionnaire mailing procedure consisted of the following steps:

1. Advance notice letter:

Sent to all potential respondents three days before the questionnaire. Mailed lst class in a business-sized envelope.

2. First mailing of the questionnaire with first accompanying letter:

Sent to all potential respondents ( $50 \%$ questionnaire $\$ 1,50 \%$

Questionnaire $\#_{2}$ ). In an effort to obtain a balanced

distribution of male and female respondents in the Hazardous

Facility and General Community groups, $50 \%$ of the accompanying

letters for each Questionnaire contained a request for a male respondent if possible, the remaining $50 \%$ of the accompanying letters contained a request for a female respondent. The accompanying letters for the other groups of potential respondents contained no reference to sex. Each individual questionnaire together with its accompanying letter and an addressed, postage-paid business reply envelope was mailed lst class in a $9^{\prime \prime} \times 12^{\prime \prime}$ manila envelope. 
3. Second mailing of the questionnaire with second accompanying letter:

Sent to all potential respondents from whom neither a returned questionnaire nor an indication of non-deliverability was received within twelve days of the first mailing. The enclosures in the mailing were identical to those in the first mailing, except of course that the accompanying letter referred to the lack of response to the earlier mailing.

4. Third mailing of the questionnaire with third accompanying letter:

Sent to all potential respondents from whom neither a returned questionnaire nor an indication of non-deliverability was received within twelve days of the second mailing. The enclosures in this mailing differed from those in the second mailing only in that the accompanying letter referred to the lack of response to the two previous mailings and stated that the third mailing would be the last. Whereas the first and second mailings were mailed first class, the third mailing was sent first class, Special Delivery.

5. Response deadline:

In order to facilitate orderly data processing, no responses received later than a deadline set at three weeks following the final mailing were included in the analyses.

\section{Response Rates}

A sumary of the response rates (Dillman, 1978:49-53) for all of the groups included in this study is presented in Table 1 . The seven columns 
TABLE 1

Response Hates for All Groups

\begin{tabular}{|c|c|c|c|c|c|c|c|}
\hline Name of Group & Seut & $\begin{array}{c}\text { Nol } \\
\text { Deliverable }\end{array}$ & $\begin{array}{l}\text { Potential } \\
\text { Respondents }\end{array}$ & $\begin{array}{l}\text { Helurns, } \\
\text { Acceptable }\end{array}$ & $\begin{array}{l}\text { Racurns, } \\
\text { Unacceptable }\end{array}$ & $\begin{array}{l}\text { Returns, } \\
\text { Tolal }\end{array}$ & $\begin{array}{l}\text { Percent age } \\
\text { Returned }\end{array}$ \\
\hline \multicolumn{8}{|l|}{ General comumities } \\
\hline San Francisco & 103 & 21 & 82 & 31 & 4 & 35 & 42.7 \\
\hline Houston & 119 & 39 & 80 & 22 & 2 & 24 & 30.0 \\
\hline libicago & 116 & 23 & 93 & 22 & 15 & 37 & 39.8 \\
\hline Detroit & 124 & $1 / 4$ & 110 & 36 & 9 & 45 & 40.9 \\
\hline Buston & 116 & 22 & 94 & 40 & 5 & 45 & 47.9 \\
\hline Al lanta & 119 & 25 & $9 / 4$ & 33 & 5 & 38 & 40.4 \\
\hline TOTAl. & 697 & 144 & 553 & 184 & 40 & 224 & 40.5 \\
\hline \multicolumn{8}{|l|}{ Ilarandus-facility Communities } \\
\hline konl Wing, Minnesola & 126 & 33 & 93 & 40 & 7 & 47 & 50.5 \\
\hline Waterford, Commecticut & 118 & 12 & 106 & 52 & h & 58 & 54.7 \\
\hline tivereft, Massachusetts & 112 & 20 & 92 & 34 & 5 & 39 & 42.4 \\
\hline Savammah, Georgia & 115 & 25 & 90 & 26 & 8 & 34 & 37.8 \\
\hline roesyth/colstrip, Montans & 112 & 6 & 106 & 33 & 5 & 38 & 35.8 \\
\hline Publo, Colorado & 111 & 20 & 91 & 44 & 7 & 51 & 56.0 \\
\hline TOTAL. & 694 & 116 & 578 & 229 & 38 & 267 & 461.2 \\
\hline \multicolumn{8}{|l|}{ Envirmmentalists } \\
\hline Wostern & 49 & 1 & 48 & is & 4 & 39 & 81.2 \\
\hline Eastern & 100 & 1 & 99 & 75 & 3 & 78 & 78.8 \\
\hline National & 98 & 1 & 97 & 65 & 8 & 73 & 15.2 \\
\hline TOTAL & 247 & 3 & 244 & 175 & 15 & 190 & 77.9 \\
\hline Nuclear lingineers & 96 & 0 & 96 & 82 & 1 & 83 & 86.4 \\
\hline Chemical Engineers & 99 & 4 & 95 & 72 & 2 & 74 & 77.9 \\
\hline Science Writers & 206 & 1 & 203 & $m$ & 20 & 97 & 17.8 \\
\hline CRANI TUTAI. & 2039 & 270 & 1769 & 819 & 118 & 936 & 52.9 \\
\hline
\end{tabular}


in the table are defined as follows:

1. Sent: The number of questionnaires mailed in the first mailing; the gross number of potential respondents.

2. Not Deliverable: The number of questionnaires returned by the Post Office due to their inability to locate the addressee.

3. Potential Respondents (Net): The number of potential respondents who presumably received a questionnaire; the number sent minus the number not deliverable.

4. Returns, Acceptable: The number of questionnaires returned that included usable data.

5. Returns, Unacceptable: The number of questionnaires returned for which the data were not usable.

6. Returns, Total: The sum of the Returns, Acceptable and Unacceptable.

7. Percentage Returned: Total Returns divided by Potential Returns. This is the response rate.

The total response rate for all groups was $52.9 \%$. The response rates for the 6 major groups ranged from $40.5 \%$ for the General Communities to $86.4 \%$ for the Nuclear Engineers. These different response rates were not surprising. On the basis of previous studies (e.g., Dillman, 1978:29-32), one would expect that a questionnaire dealing with a specific topic such as nuclear waste management would evoke higher response rates from established groups whose members are known to be interested in that topic than from groups whose members have no known interest in it. This pattern of response rates holds true for all of the groups in the study. The General Comnunities, the Hazardous Facility 
Communities and the Science Writers all had response rates in the $40^{\prime} \mathrm{s}$. The only surprise here is the Science Writers, a group presumably more interested in technical topics than the general public. Based on an analys is of the Incomplete Returns (see Earle, et al., 1981), the relatively low response rate for the Science Writers appeared to be due to the lack of time and to ethical considerations. The

Environmentalists, the Nuclear Engineers and the Chemical Engineers had response rates in the $70^{\prime}$ s or $80^{\prime}$ s, as expected. The total response rate of $52.9 \%$ was composed, then, of high response rates and moderate response rates. The lower response rates were associated with lack of specific interest in the central topic of the survey.

As pointed out above in the section on mailing procedures, respondents were grouped into three distinct sets: a) Set $\#_{1} 1$, those $(N=428)$ who responded to the tasks unique to Questionnaire $\left.k_{1} 1 ; b\right)$ Set $k_{1} 2$, those ( $N=391$ ) who responded to the tasks unique to Questionnaire 非; and c) Set $k_{3}$, those $(N=819)$ who responded to the tasks common to both questionnaires (the total set of respondents). The task described in this report was contained in both questionnaires, and the respondents therefore were those of Set 非. Complete analyses of the demographic characteristics of these respondents are presented in a companion report (Earle, et al., 1981). The demographic comparisons among the respondent groups are summarized here in Table 2. The entries in Table 2 compare the groups on the left margin with those on the top margin. Thus, the General Communities had a greater proportion of male respondents than did the Environmentalists. Only significant differences are entered. 
TABI.E 2

Sunmary of Demographlc Comparisons Among Respondent firoups

\begin{tabular}{|c|c|c|c|c|c|c|c|}
\hline Group & $\begin{array}{l}\text { Character- } \\
\text { istics }\end{array}$ & $\begin{array}{c}\text { General } \\
\text { Comnunities }\end{array}$ & $\begin{array}{l}\text { Hazardous } \\
\text { Facility } \\
\text { Communities }\end{array}$ & $\begin{array}{l}\text { Environ- } \\
\text { mentalists }\end{array}$ & $\begin{array}{l}\text { Science } \\
\text { Writers }\end{array}$ & $\begin{array}{l}\text { Chemical } \\
\text { Engineers }\end{array}$ & $\begin{array}{l}\text { Nuclear } \\
\text { Engineers }\end{array}$ \\
\hline \multirow{6}{*}{$\begin{array}{l}\text { General } \\
\text { Communities }\end{array}$} & Sex & & & + Male & & - Male & - Male \\
\hline & Education & & + & - & - & - & - \\
\hline & Employment Status & & + students & + ot udents & - employed & - employed & - employed \\
\hline & Occupation & & $\begin{array}{l}\text { - blue collar } \\
\text { - white collar }\end{array}$ & $\begin{array}{l}\text { + blue collar } \\
\text { - edecation \& } \\
\text { professionals }\end{array}$ & - writers & - eng incers & - engineers \\
\hline & Income & & + & - & - & - & - \\
\hline & Age & & & & & & older \\
\hline \multirow{6}{*}{$\begin{array}{l}\text { Hazardous } \\
\text { Facility } \\
\text { Commonties }\end{array}$} & Sex & & & + male & & - male & - male \\
\hline & Education & - & & - & - & - & - \\
\hline & Employment Status & + retired & & + retired & - employed & - employed & - ermployed \\
\hline & Occupation & $\begin{array}{l}\text { + blue collar, } \\
\text { - white collar } \\
\text { professionals }\end{array}$ & & $\begin{array}{l}\text { + blue collar, } \\
\text { - education \& } \\
\text { professionals }\end{array}$ & - writers & - engineers & - eng ineers \\
\hline & Incone & - & & - & - & - & - \\
\hline & Age & & & & & & older \\
\hline \multirow{6}{*}{$\begin{array}{l}\text { Environ- } \\
\text { mentalists }\end{array}$} & Sex & - male & - male & & - male & - male & - male \\
\hline & Education & + & + & & & - & - \\
\hline & Employment Status & + retired & & t recired & - employed & - enployed & - employed \\
\hline & Occupation & $\begin{array}{l}\text { - blue collar, } \\
\text { + education \& } \\
\text { professionals }\end{array}$ & $\begin{array}{l}\text { - blue collar, } \\
\text { t etucation } 8 \\
\text { professionals }\end{array}$ & & - writers & - engineers & - engineers \\
\hline & Incone & + & + & & - & - & - \\
\hline & Age & & & & & & older \\
\hline
\end{tabular}


TABIE 2 (continued)

\begin{tabular}{|c|c|c|c|c|c|c|c|}
\hline Group & $\begin{array}{l}\text { Character- } \\
\text { istics }\end{array}$ & $\begin{array}{c}\text { General } \\
\text { Communities }\end{array}$ & $\begin{array}{l}\text { Hazardous } \\
\text { Facility } \\
\text { Communities }\end{array}$ & $\begin{array}{c}\text { Envirou- } \\
\text { inentalists }\end{array}$ & $\begin{array}{l}\text { Science } \\
\text { Wricers }\end{array}$ & $\begin{array}{l}\text { Chemical } \\
\text { Engineers }\end{array}$ & $\begin{array}{l}\text { Nuclear } \\
\text { Engineers }\end{array}$ \\
\hline \multirow{6}{*}{$\begin{array}{l}\text { Science } \\
\text { Writers }\end{array}$} & $\operatorname{sex}$ & & & + male & & - male & - male \\
\hline & Education & + & + & & & - & - \\
\hline & Eup loyment Status & + employed & + employed & + employed & & - employed & - enployed \\
\hline & Occupation & + writers & + writers & + writers & & - engineers & - engineers \\
\hline & Income & + & + & + & & - & \\
\hline & Age & & & & & & older \\
\hline \multirow{6}{*}{$\begin{array}{l}\text { Chemical } \\
\text { Engineers }\end{array}$} & Sex & t male & tinale & + male & t male & & \\
\hline & Welucation & + & + & + & + & & - \\
\hline & Employment Status & t employed & + employed & + employed & + employed & & \\
\hline & Occupation & + engineers & + eng ineers & + engineers & + eng ineers & & \\
\hline & Inc one & + & + & + & + & & - \\
\hline & Age & & & & & & older \\
\hline \multirow{6}{*}{$\begin{array}{l}\text { Nuclear } \\
\text { Eng ineers }\end{array}$} & Sex & + male & + male & + male & t male & & \\
\hline & Education & + & + & + & + & + & \\
\hline & Employment Status & + enip loyeal & t employed & t employed & + employed & & \\
\hline & Occupation & + engineers & + engineers & + engineers & + engiveers & & \\
\hline & Incone & + & + & + & & - & \\
\hline & Age & younger & younger & younger & younger & younger & \\
\hline
\end{tabular}


The task exploring the perception of risks associated with hazardous facilities contained eight items. The items were preceded by a brief introduction which defined a hazardous facility as "any sort of industrial facility that could adversely affect the health and safery of people." The first four items probed different aspects of respondents' perceptions of "the closest hazardous facility that concerns you." Respondents were asked how close that facility was to them, what it was, what sorts of risk were associated with it and what persons were placed at risk by it. The next two items concerned the risks of a toxic chemical disposal facility, and the final two items explored the perceived risks of a nuclear waste disposal facility.

Item 非. The first item asked respondents, "How near to your residence is the closest hazardous facility that concerns you?" Respondents circled one of eight response alternatives, as shown on the distance dimension of Table 3. The eighth alternative read, "There is no hazardous facility that concerns me within 50 miles of my residence. The closest hazardous facility is miles away." Table 3 gives the cumulative percentages of respondents within groups who indicted the existence of a hazardous facility within a given distance of their residences. The Total row shows that $49.5 \%$ of all respondents indicated the existence of a hazardous facility within ten miles of their residences, but that $14 \%$ knew of no facility within fifty miles that they would consider to be hazardous and of personal concern.

The highly significant $x^{2}$ for Table 3 and the Cramer's $V$ of 0.17 indicate that groups and distances were related. The differences among 
TABIR 3

Cumulative Percentage of Reepondente Hio Indicated the Exiatence of llazardous Pacillty Mear Their Residence, by Dítance

\begin{tabular}{|c|c|c|c|c|c|c|c|c|}
\hline \multirow[b]{2}{*}{ GROUP } & \multicolumn{8}{|c|}{ DISTANCE (MILES) } \\
\hline & $<1 / 2$ & $1 / 2-1$ & $1-2$ & $2-5$ & $5-10$ & $10-20$ & $20-50$ & so \\
\hline General Comounfties & 4.6 & 9.2 & 16.7 & 27.0 & 39.1 & 54.0 & 81.6 & 100.0 \\
\hline $\begin{array}{l}\text { Hazerdous fecillty } \\
\text { Commitlos }\end{array}$ & 6.7 & 18.4 & 31.4 & 53.8 & 65.5 & 76.7 & 87.9 & 100.0 \\
\hline Env f ronment al iste & 4.1 & 7.0 & 12.8 & 29.2 & 49.7 & 20.8 & 88.9 & 100.0 \\
\hline Science Hriters & 2.7 & 2.7 & 5.4 & 17.7 & 30.0 & 49.2 & 79.3 & 100.0 \\
\hline Chemical Engineer & 1.4 & 2.8 & 12.9 & 27.4 & 50.6 & 76.7 & 91.2 & 100.0 \\
\hline Huclear Engineer. & 0.0 & 2.6 & 6.4 & 17.9 & 44.8 & 65.3 & 84.5 & 100.0 \\
\hline TOTAL & 4.2 & 9.5 & 17.6 & 33.3 & 49.5 & 66.8 & 86.0 & 100.0 \\
\hline
\end{tabular}

Cramer $^{\prime} v=0.17$ 
groups in their perceptions of the proximity of the closest hazardous facility can be seen in simplified form in Table 4 which presents group rankings for the first five distance categories. (The remaining three categories were not included because they contain very little information due to a "ceiling effect.") The rankings for the first five categories were averaged to produce a mean ranking for each group. The relative positions of the six groups, based on the mean rankings, are presented at the bottom of Taile 4. The Hazardous Facility Communities group was ranked number one; indicating that members of that group were aware of hazardous facilities at closer distances than were the other groups. This result is due in part to the sample selection procedure whereby the Hazardous Facility Communities respondents were chosen partially on the basis of their proximity to specific hazardous facilities. It must be stressed, however, that respondents' judgments were not completely constrained by this factor. There was still a large subjective component since what is considered to be a hazardous facility by one respondent may not be so considered by another. Similarly, what was taken to be a hazardous facility by the investigators may not have been seen as such by some respondents. Nonetheless, overall, Hazardous Facility Cormunities reported themselves to 1 ive closer to hazardous facilities than did other respondent groups, notably the General Communities.

The mean rankings of three groups, the General Communities, the Environmentalists and the Chemical Engineers, fell near the middle of the scale. The similarity of these three groups to one another does not necessarily mean that they shared similar objective distances from certain types of facilities. Since a respondent's judgment is based 
TABLE 4

Group Rankings for First Five Distance Categories

\begin{tabular}{|c|c|c|c|c|c|c|}
\hline \multirow[b]{2}{*}{ GrouP } & \multicolumn{6}{|c|}{ DIstance (hILES) } \\
\hline & $<1 / 2$ & $1 / 2-1$ & $1-2$ & $2-5$ & $5-10$ & $\overline{\mathbf{x}}$ \\
\hline General Communftied (a) & 2 & 2 & 2 & 4 & 5 & 3.0 \\
\hline $\begin{array}{l}\text { Hazardoug racility } \\
\text { Commenities (b) }\end{array}$ & 1 & 1 & 1 & 1 & $\mathbf{1}$ & 1,0 \\
\hline Env Ironment al iato (c) & 3 & 3 & 4 & 2 & 3 & 3.0 \\
\hline Sclence Hritera (d) & 4 & 5 & 6 & 6 & 6 & 5.4 \\
\hline Clıewical Engineers (e) & 5 & 4 & 3 & 3 & 2 & 3.4 \\
\hline Huclear Engineer: (f) & 6 & 6 & 5 & 5 & 4 & 5.2 \\
\hline
\end{tabular}

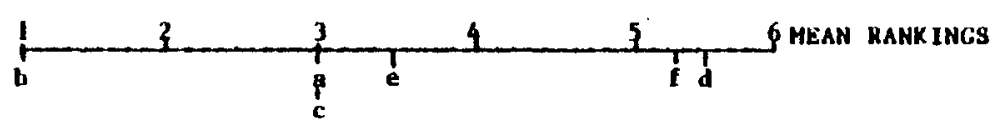


first on the existence of a facility and second on the respondent's perception of hazards produced by that facility, respondents could have similar distance judgments but be concerned about entirely different sorts of facilities. We will explore this point further when we disuss the second item in this section.

The high end of the distance-ranking scale was occupied by the Science Writers and the Nuclear Engineers. Again, as above, it is not possible to determine whether the large distances reported by these two groups were due to objectively greater distances from any hazardous facilities or due to relative lack of concern for the possible hazards of these facilities.

Item 非. The second item, referring to the "closest hazardous facility that concerns you," asked respondents "What sort of hazardous facility is it?" Respondents were free to write in any response that seemed to them to be appropriate. A sample of these free responses was examined, and fourteen categories of facilities were constructed. The remaining responses were individually coded as belonging to one of the fourteen categories. Table 5 shows the fourteen facility categories crossed with the distance categories. The entries in Table 5 are the cumlative percentages of all respondents who identified a given facility within a given distance of their residences. As can be seen in the "\% of Total $\mathrm{N}^{\prime \prime}$ column, the most frequently identified hazardous facility was Nuclear Power Plant, identified by $34 \%$ of the respondents. The top six facilities also included General Heavy Industry (13.7\%), Chemical Production, etc. (8.1\%), Waste Disposal Facility (7.4\%), $0 i 1$ Refinery/Petrochemical $(7.2 \%)$ and Coal-Fired Power Plant (7.0\%). 
TABLE 5

Cumulative Percentage of Respondento Who Identified a Given llazadiou Facility, by distance

\begin{tabular}{|c|c|c|c|c|c|c|c|c|c|c|}
\hline \multirow[b]{2}{*}{ FACILITY } & \multirow[b]{2}{*}{$<1 / 2$} & \multirow[b]{2}{*}{$1 / 2-1$} & \multirow[b]{2}{*}{$1-2$} & \multirow[b]{2}{*}{$2-5$} & \multicolumn{2}{|c|}{ DISTANCE (HILES) } & \multirow[b]{2}{*}{$20-50$} & \multirow[b]{2}{*}{$>50$} & \multirow[b]{2}{*}{ N } & \multirow[b]{2}{*}{$\begin{array}{c}z \text { of } \\
\text { Total }\end{array}$} \\
\hline & & & & & $5-10$ & $10-20$ & & & & \\
\hline Nuclear Yower Plant & 2.4 & 6.1 & 12.2 & 25.1 & 37.6 & 55.2 & 81.9 & 100.0 & 255 & 34.0 \\
\hline General heavy Induatry & 3.9 & 8.8 & 18.5 & 43.1 & 68.0 & 85.5 & .96 .2 & 100.0 & 103 & 13.7 \\
\hline Clienical Production, Etc. & 9.8 & 16.4 & 24.6 & 45.9 & 68.9 & 86.9 & 96.1 & 100.0 & 61 & 0.1 \\
\hline Waste Diaposal Facility & 0 & 5.4 & 10.8 & 26.9 & 51.9 & 80.5 & 93.0 & 100.0 & 56 & 1.4 \\
\hline dil Refinery/Petrochemical & 5.6 & 1.5 & 14.9 & 29.1 & 50.1 & 16.0 & 98.2 & 100.0 & 54 & 7.2 \\
\hline Coal-Fired Power Plant & 13.2 & 22.6 & 30.1 & 41.4 & 54.6 & 62.1 & 97.9 & 100.0 & 53 & 7.0 \\
\hline oclier & 7.1 & 11.9 & 26.2 & 47.6 & 54.7 & 76.1 & 97.5 & 100.0 & 42 & 5.6 \\
\hline ING/LPG Storage, Etc. & 2.9 & 22.9 & 54.3 & 71.4 & 91.4 & 97.1 & 100.0 & 100.0 & 35 & 4.7 \\
\hline Research Facility & 0 & 0 & 10.3 & 31.0 & 48.2 & 68.9 & 93.0 & 100.0 & 29 & 3.9 \\
\hline Nuclear Weapons/be fenae & 4.8 & 4.8 & 9.6 & 33.4 & 57.2 & 76.2 & 85.1 & 100.0 & 21 & 2.8 \\
\hline Don't know & 0 & $\mathbf{0}$ & 0 & 5.6 & 5.6 & 11.2 & 22.3 & 100.0 & 18 & 2.4 \\
\hline Power Plant (Unspecified) & 16.7 & 33.4 & 41.7 & 58.4 & 75.1 & 75.1 & 91.8 & 100.0 & 12 & 1.6 \\
\hline None & - & - & - & - & - & - & - & 100.0 & 8 & 1.1 \\
\hline Oil-fired Power Plant & 0 & $\mathbf{0}$ & 0 & $\mathbf{0}$ & 25.0 & 50.0 & 75.0 & 100.0 & 4 & 0.5 \\
\hline TOTAL & 4.2 & 9.5 & 17.6 & 33.3 & 49.5 & 66.8 & 86.0 & 100.0 & 751 & 100.0 \\
\hline
\end{tabular}


In order to investigate the relationship between facilities and distances, the top six facilities were ranked within each of the first five distance categories. As Table 6 shows, the five rankings were averaged for each facility to produce a set of mean rankings. The relative positions of the top six facilities, based on the mean rankings, are presented at the bottom of Table 6 . This set of ranikings provides an indirect indication of how close those repondents who lived near what they consider to be a hazardous facility are willing to live near it. For example, those who considered Chemical Production, etc. to be hazardous 1 ived closer to it than those who considered Waste Disposal Facility to be hazardous lived to it. Perhaps the most notable result here is that the most frequently identified hazardous facility, Nuclear Power Plant, was also tied for being the most distant of the top six facilities. This result is an indication of how strongly risk is associated with Nuclear Power by the public. While two of the six Hazardous Facility Communities were chosen in part on the basis of their proximity to Nuclear Power Plants, the remaining respondents were chosen without regard to Nuclear Power. Thus, for more than one third of those who responded to this item to identify a Nuclear Power Plant as the closest facility, many of them must have had to reject some closer candidate facilities. The fact that Nuclear Power Plant tied for being the most distant of the top six facilities supports this notion.

Some further insight into the relative perceived hazard of various facilities can be seen in Table 7 where the distributions of facilities within groups are displayed. The differences in distributions among groups were highly significant $\left(\chi_{(6 \overline{5})}^{2} 217.65 ;\right.$ Cramer's $\left.v=0.24\right)$. Note 
TAHLE 6

Hazardous Facility Rankings for First Five bistance Calegories

\begin{tabular}{|c|c|c|c|c|c|c|}
\hline \multirow[b]{2}{*}{ FACII.LTY } & \multicolumn{6}{|c|}{ DISTANCE (hILES) } \\
\hline & $<1 / 2$ & $1 / 2-1$ & $1-2$ & $2-5$ & $5-10$ & $\vec{x}$ \\
\hline Nuclear Power Plant (a) & 5 & 5 & 5 & 6 & 6 & 5.4 \\
\hline Ceneral lleavy lindustry (b) & 4 & $\mathbf{3}$ & 3 & 2 & 2 & 2.8 \\
\hline $\begin{array}{l}\text { Chemical Production, } \\
\text { Elc. (c) }\end{array}$ & 2 & 2 & 2 & 1 & 1 & 1.6 \\
\hline Waste Disposal Facility (d) & 6 & 6 & 6 & 5 & 4 & 5.4 \\
\hline $\begin{array}{l}\text { Dil Refinery/ } \\
\text { Pelrochemical (e) }\end{array}$ & 3 & 4 & 4 & 4 & 5 & 4.0 \\
\hline Cual-fired Power Plant (f) & 1 & 1 & 1 & 3 & $\mathbf{3}$ & 1.8 \\
\hline
\end{tabular}

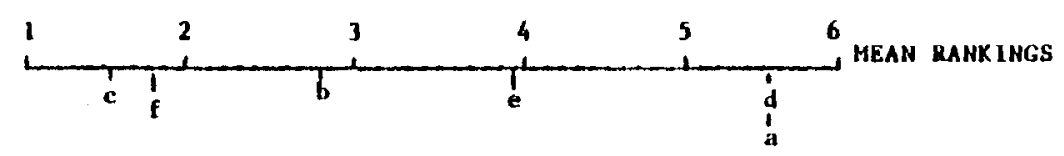


TABIE 7

Closegt llazardour Facility. By Group

\begin{tabular}{|c|c|c|c|c|c|c|c|}
\hline \multirow[b]{2}{*}{ FACIIITY } & \multirow[b]{2}{*}{$\begin{array}{l}\text { General } \\
\text { Communities }\end{array}$} & \multicolumn{5}{|c|}{ GROUP } & \multirow[b]{2}{*}{ Total } \\
\hline & & $\begin{array}{l}\text { Hazardous } \\
\text { facilities } \\
\text { Conmunities }\end{array}$ & $\begin{array}{l}\text { Environ- } \\
\text { aentalists }\end{array}$ & $\begin{array}{l}\text { Science } \\
\text { Writers }\end{array}$ & $\begin{array}{l}\text { Chemical } \\
\text { Engineers }\end{array}$ & $\begin{array}{l}\text { Nuclear } \\
\text { Engineers }\end{array}$ & \\
\hline Nuclear Power Plant & 29.0 & 41.9 & 43.2 & 41.2 & 20.3 & 8.1 & 34.1 \\
\hline General lleavy Induatry & 14.8 & 16.1 & 9.5 & 7.4 & 11.6 & 21.6 & 13.7 \\
\hline Chemical Production, Ecc. & 8.0 & 7.8 & 4.7 & 5.9 & 14.5 & 13.5 & 8.2 \\
\hline Waste Disposal Facility & 7.4 & 0.0 & 12.4 & 7.4 & 17.4 & 8.1 & 7.4 \\
\hline oil Refinery/Pecrochemical & 14.8 & 0.9 & 7.1 & 7.4 & 11.6 & 4.1 & 7.1 \\
\hline Coul-fired Power Plant & 2.5 & 10.6 & 3.0 & 5.9 & 4.3 & 18.9 & 7.0 \\
\hline other & 4.3 & 6.0 & 7.1 & 4.4 & 2.9 & 6.8 & 5.5 \\
\hline LNG/LPC Storage, Etc. & 1.2 & 9.7 & 5.9 & 0.0 & 0.0 & 2.7 & 4.6 \\
\hline Research Facility & 6.2 & 0.9 & 1.8 & 4.4 & 8.7 & 6.8 & 3.8 \\
\hline Nuclear Weapons/Defense & 0.6 & 2.3 & 3.6 & 2.9 & 4.3 & 5.4 & 2.8 \\
\hline Don't Know & 4.9 & 1.4 & 0.0 & 7.4 & 1.4 & 2.7 & 2.5 \\
\hline Power Plant (Unspecified) & 3.1 & 1.4 & 1.2 & 2.9 & 0.0 & 0.0 & 1.6 \\
\hline Hone & 2.5 & 0.9 & 0.6 & 0.0 & 1.4 & 1.4 & 1.2 \\
\hline Oil-fired Power Plant & 0.6 & 0.0 & 0.0 & 2.9 & 1.4 & 0.0 & 0.5 \\
\hline
\end{tabular}

$x^{2}(65)-217.65 ; p<.001$

Cramer's $V=0.24$ 
particularly that Nuclear Power Plant was the most frequently chosen facility by all groups except the Nuclear Engineers. In the case of the Nuclear Engineers, it is not possible to tell with these data whether their low rate of selection for Muclear Power Plant was due to actual distance or to a lack of perception of that type of facility as hazardous. Most likely both factors contributed. With the remaining groups, Nuclear Power Plant is clearly overrepresented. That is, Nuclear Power Plant was considered to be more hazardous than the other facilities. This can be seen by considering that, without the Nuclear Engineers, $37 \%$ of the total sample chose a Nuclear Power Plant as being the closest hazardous facility to their residence.

Several individual comparisons in Table 7 are of interest. First of all, let us examine the General Commities and Hazardous Facility Communities columns. If respondents' judgments reflected actual distances, we would expect the Hazardous Facility Commities to have higher percentages than the General Communities of their closest hazardous facility judgments devoted to Nuclear Power Plant, Coal-Fired Power Plant and LNG/LPG Storage, etc., the facility for which they were selected. Table 7 shows that this is true. Table 7 also shows that the General Communities had higher percentages devoted to Don't know and None, lending further support to the general distinction between the two public groups. The second set of comparisons in Table 7 is between the Chemical and Nuclear Engineers. Here we see that each group of engineers reported as hazardous a facility associated with the other group rather than one associated with itself. Either they did, by some remarkable coincidence, happen to live closer to the other facilities, or they 
simply didn't consider the facilities connected with their own work to be particularly hazardous. As we have already noted, Chemical Engineers, quite unlike Nuclear Engineers, considered a Nuclear Power Plant to be the closest hazardous facility. For Nuclear Engineers, General Heavy Industry was the most frequently mentioned hazardous facility and Coal-Fired Power Plant was second. Both of these facilities drew far smaller percentages of judgments from Chemical Engineers.

For all but one of the identified hazardous facilities, there was no statistically significant $(p<.001)$ relationship between groups and distances. For Nuclear Power Plant, groups and distances were significantly related $\left(x_{(35)}^{2}=104.03\right.$; Cramer's $\left.V=0.28\right)$. The relation was primarily due to the short-distance judgments of the Hazardous Facility Commities compared with the long-distance judgments of the remaining groups. For example, $52.8 \%$ of the Hazardous Facility Commities group ( $18.8 \%$ of all those who selected Nuclear Power Plant) indicated a distance within five miles of their residence. For all the remaining groups combined, only $6.3 \%$ of the respondents reported living within five miles of a nuclear power plant. Since Nuclear Power Plant was the facility for which two of the Hazardous Facility Comunities were selected, this result is expected. Results for the other two facilities for which Hazardous Facility Communities were selected, Coal-Fired Power Plant and LNG/LPG Storage, were similar to those for Nuclear Power Plant, but the relatively small numbers of respondents who mentioned those facilities precluded statistical significance.

Item 非. Again referring to the "closest hazardous facility that concerns you," the third itern asked respondents, "What specific sorts of 
risk are associated with the facility?" As with the previous item, a sample of the respondents' free responses was examined, and fifteen risk categories were constructed. The remaining responses were each coded as belonging to one of the fifteen categories. Table 8 shows the fifteen risk categories crossed with the facility categories. A quick glance at Table 8 makes it imediately clear that facilities and risks were strongly related; each facility had its own unique distribution of risks. Since there were no statistically significant differences among groups in their association of risks within individual facilities, the general patterns of risk-facility association across groups can be described.

1. Nuclear Power Plant. The general risk pattern for this facility was dominated by Leak of Radioactive Materials (58.8\%), followed by Nuclear Accident ( $14.8 \%$ ). Note that $3.6 \%$ of the respondents who selected a Nuclear Power Plant as being the closest hazardous facility associated a Nuclear Core Meltdown with it, and $2.8 \%$ nominated Explosion.

2. General Heavy Industry. Pollution ( $71.6 \%$ ) was by far the primary risk associated with this facility.

3. Chemical Production. There were several important risks here, lead by Pollution (27.9\%), Leak of Toxic Materials (23.0\%), Explosion (14.8\%) and Transportation Accident (11.5\%).

4. Waste Disposal Facility. Three risks were predominant, Pollution (34.6\%), Leak of Toxic Materials (26.9\%) and Health Effects $(21.2 \%)$. 
TAHLE :

Type of Hisk Associated with the Closest llazardous facility,

by facility

\begin{tabular}{|c|c|c|c|c|c|c|c|c|c|c|c|c|}
\hline \multirow[b]{2}{*}{ TYPE OF RISK } & \multicolumn{2}{|c|}{$\begin{array}{l}\text { Nuclear } \\
\text { Power Plant }\end{array}$} & \multicolumn{2}{|c|}{$\begin{array}{l}\text { General Heavy } \\
\text { Induatry }\end{array}$} & \multicolumn{2}{|c|}{$\begin{array}{l}\text { Chemical } \\
\text { Production }\end{array}$} & \multicolumn{2}{|c|}{$\begin{array}{l}\text { Waste Disposal } \\
\text { Facility }\end{array}$} & \multicolumn{2}{|c|}{$\begin{array}{l}\text { oil Refinery/ } \\
\text { Petrochewical }\end{array}$} & \multicolumn{2}{|c|}{$\begin{array}{l}\text { Coal-Fired } \\
\text { Power Plant }\end{array}$} \\
\hline & N & $x$ & $\mathbf{N}$ & $x$ & N & $x$ & N & $x$ & $\mathbf{N}$ & $x$ & $\mathbf{N}$ & $x$ \\
\hline Pollution (Contamination) & 14 & 5.6 & 73 & 71.6 & 17 & 27.9 & 18 & 34.6 & 25 & 48.1 & 41 & 78.8 \\
\hline Leak of radioactive material & 147 & 58.8 & 1 & 1.0 & 0 & 0.0 & 2 & 3.8 & $\mathbf{0}$ & 0.0 & o & 0.0 \\
\hline Explosion & 7 & 2.8 & 7 & 6.9 & 9 & 14.8 & 2 & 3.8 & $y$ & 17.3 & $\mathbf{0}$ & 0.0 \\
\hline Leak of Toxic Materials & 3 & 1.2 & 2 & 2.0 & 14 & 23.0 & 14 & 26.9 & 3 & 5.8 & 2 & 3.8 \\
\hline Nuclear Accident & 37 & 14.8 & o & 0.0 & $\mathbf{0}$ & 0.0 & 0 & 0.0 & $\mathbf{0}$ & $\mathbf{0 . 0}$ & 0 & 0.0 \\
\hline llealth Effects & 5 & 2.0 & 6 & 5.9 & 4 & 6.6 & 11 & 21.2 & 2 & 3.8 & 4 & 7.7 \\
\hline fire & 1 & 0.4 & 5 & 4.9 & 3 & 4.9 & 1 & 1.9 & 12 & 23.1 & 0 & 0.0 \\
\hline Don't Know & 7 & 2.8 & 2 & 2.0 & 4 & 6.6 & $\mathbf{1}$ & 1.9 & 0 & 0.0 & 1 & 1.9 \\
\hline other & 7 & 2.8 & 2 & 2.0 & 3 & 4.9 & 1 & 1.9 & $\mathbf{0}$ & 0.0 & $\mathbf{0}$ & 0.0 \\
\hline None & 5 & 2.0 & 1 & 1.0 & 0 & 0.0 & 1 & 1.9 & $\mathbf{0}$ & 0.0 & $\mathbf{3}$ & 5.8 \\
\hline Hlunan Error & 6 & 2.4 & $\mathbf{0}$ & 0.0 & $\mathbf{0}$ & 0.0 & 0 & 0.0 & $\mathbf{l}$ & 1.9 & $\mathbf{0}$ & 0.0 \\
\hline l.eak of I.MG & 0 & $\mathbf{0 . 0}$ & 2 & 2.0 & $\mathbf{0}$ & 0.0 & 1 & 1.9 & $\cdot 0$ & 0.0 & 1 & 1.9 \\
\hline Trausportation Accident & 1 & 0.4 & l & 1.0 & 7 & 11.5 & 0 & 0.0 & 0 & 0.0 & 0 & 0.0 \\
\hline Nuclear Core Heltuown & 9 & 3.6 & $\mathbf{0}$ & $\mathbf{0 . 0}$ & $\mathbf{0}$ & 0.0 & 0 & 0.0 & $\mathbf{0}$ & 0.0 & 0 & 0.0 \\
\hline Genclic Effects & 1 & 0.4 & 0 & 0.0 & 0 & 0.0 & $\mathbf{0}$ & 0.0 & 0 & 0.0 & 0 & 0.0 \\
\hline TOTAL & 250 & 100.0 & 102 & 100.0 & 61 & 100.0 & 52 & 100.0 & 52 & 100.0 & 52 & 100.0 \\
\hline
\end{tabular}


TABLE 8 (continued)

\begin{tabular}{|c|c|c|c|c|c|c|c|c|c|c|c|c|}
\hline \multirow[b]{2}{*}{ TYIE: OF KLSK } & \multicolumn{2}{|c|}{ other } & \multicolumn{2}{|c|}{$\begin{array}{l}\text { I.NC/L.PG } \\
\text { Storage, etc. }\end{array}$} & \multicolumn{2}{|c|}{$\begin{array}{l}\text { Research } \\
\text { Facility }\end{array}$} & \multicolumn{2}{|c|}{$\begin{array}{l}\text { Nuclear Weaponal } \\
\text { Defense }\end{array}$} & \multirow{2}{*}{$\frac{\operatorname{Don}^{\circ} t}{N}$} & \multirow{2}{*}{$\frac{\text { Know }}{x}$} & \multicolumn{2}{|c|}{$\begin{array}{l}\text { Power Plant } \\
\text { (Unspecified) }\end{array}$} \\
\hline & N & $x$ & $n$ & $x$ & N & $x$ & N & $x$ & & & H & $x$ \\
\hline Pollution (Contamination) & 15 & 36.6 & $\mathbf{0}$ & 0.0 & 3 & 10.7 & 2 & 9.5 & $\mathbf{0}$ & 0.0 & $\mathbf{0}$ & 0.0 \\
\hline Leak of radioactive material & 2 & 4.9 & 0 & 0.0 & 9 & 32.1 & 6 & 28.6 & $\mathbf{0}$ & 0.0 & o & 0.0 \\
\hline Explusion & 6 & 14.6 & 21 & 60.0 & 1 & 3.6 & 3 & 14.3 & 1 & 7.1 & $\mathbf{0}$ & 0.0 \\
\hline leak of Toxic Materials & 了 & 7.3 & $\mathbf{0}$ & 0.0 & $\mathbf{6}$ & 28.6 & $\mathbf{1}$ & 4.8 & $\mathbf{0}$ & 0.0 & 1 & 8.3 \\
\hline Huclear Accident & 0 & 0.0 & 0 & 0.0 & 1 & 3.6 & 5 & 23.8 & 0 & 0.0 & o & 0.0 \\
\hline llealth Effecto & $\mathbf{3}$ & 7.3 & $\mathbf{0}$ & 0.0 & 1 & 3.6 & 0 & 0.0 & $\mathbf{0}$ & 0.0 & 1 & 8.3 \\
\hline fire & 1 & 2.4 & 5 & 14.3 & 1 & 3.6 & $\mathbf{0}$ & 0.0 & 0 & 0.0 & 1 & B.J \\
\hline Uon't know & 0 & 0.0 & 0 & 0.0 & l & 3.6 & 0 & 0.0 & 11 & 78.6 & 0 & 0.0 \\
\hline otlier & $\mathbf{8}$ & 19.5 & 1 & 2.9 & 2 & 7.1 & 2 & 9.5 & 0 & 0.0 & 0 & 0.0 \\
\hline None & 0 & 0.0 & 0 & 0.0 & l & 3.6 & o & 0.0 & 2 & 14.3 & $\mathbf{0}$ & 0.0 \\
\hline Juman Exror & 2 & 4.9 & 0 & 0.0 & 0 & 0.0 & $\mathbf{I}$ & 4.8 & $\mathbf{0}$ & 0.0 & 9 & 75.0 \\
\hline l.eak of I.MC & 1 & 2.4 & 7 & 20.0 & 0 & 0.0 & $\mathbf{0}$ & 0.0 & 0 & 0.0 & 0 & 0.0 \\
\hline Ir insportat ion Accident & $\mathbf{0}$ & 0.0 & 1 & 2.9 & $\mathbf{0}$ & 0.0 & $\mathbf{l}$ & 4.8 & 0 & 0.0 & 0 & 0.0 \\
\hline Nuclear Core Helldown & $\mathbf{0}$ & 0.0 & 0 & 0.0 & 0 & 0.0 & 0 & 0.0 & $\mathbf{0}$ & 0.0 & $\mathbf{0}$ & 0.0 \\
\hline Genelic Effecta & o & 0.0 & 0 & 0.0 & 0 & 0.0 & $\mathbf{0}$ & 0,0 & 0 & 0.0 & 0 & 0.0 \\
\hline TotAl. & 41 & 100.0 & 35 & 100.0 & 28 & 100.0 & 21 & 100.0 & 14 & 100.0 & 12 & 100.0 \\
\hline
\end{tabular}


Table (continued)

\begin{tabular}{|c|c|c|c|c|c|c|}
\hline \multirow[b]{2}{*}{ TYPE OF RISK } & \multicolumn{2}{|c|}{ None } & \multicolumn{2}{|c|}{$\begin{array}{l}\text { oil-rited } \\
\text { Power Plant }\end{array}$} & \multicolumn{2}{|c|}{ Total } \\
\hline & $\mathbf{N}$ & $z$ & $\mathbf{N}$ & $x$ & $\mathbf{N}$ & $x$ \\
\hline Pallution (Contanination) & 0 & 0.0 & 3 & 75.0 & 211 & 28.8 \\
\hline leak of ralioactive material & $\mathbf{0}$ & 0.0 & $\mathbf{0}$ & .0 .0 & 167 & 22.8 \\
\hline Explosion & $\mathbf{0}$ & 0.0 & 0 & 0.0 & 66 & 9.0 \\
\hline Leak of Toxic Materiala & $\mathbf{0}$ & 0.0 & $\mathbf{0}$ & 0.0 & 51 & 7.0 \\
\hline Nuclear Accident & 0 & 0.0 & $\mathbf{0}$ & 0.0 & 43 & 5.9 \\
\hline Health Effects & 0 & 0.0 & 0 & 0.0 & 37 & 5.0 \\
\hline Fire & $\mathbf{0}$ & 0.0 & 1 & 25.0 & 31 & 4.2 \\
\hline Don'l know & $\mathbf{0}$ & 0.0 & $\mathbf{0}$ & 0.0 & 27 & 3.7 \\
\hline other & $\mathbf{0}$ & 0.0 & $\mathbf{0}$ & 0.0 & 26 & 3.5 \\
\hline None & 8 & 88.9 & 0 & 0.0 & 21 & 2.9 \\
\hline Huwan Errar & 1 & 11.1 & o & 0.0 & 20 & 2.7 \\
\hline l.eak of LNC & 0 & 0.0 & $\mathbf{0}$ & 0.0 & 12 & 1.6 \\
\hline Transportation Accident & $\mathbf{0}$ & 0.0 & $\mathbf{0}$ & 0.0 & 11 & 1.5 \\
\hline Nuclear Core Melldoun & 0 & 0.0 & $\mathbf{0}$ & 0.0 & 9 & 1.2 \\
\hline Genetic Effects & $\mathbf{0}$ & 0.0 & $\mathbf{0}$ & 0.0 & 1 & 0.1 \\
\hline TOTAI. & 9 & 100.0 & 4 & 100.0 & 733 & 100.0 \\
\hline
\end{tabular}


5. Oil Refinery/Petrochemical. Again there were three leading risks, Pollution (48.1\%), Fire (23.1\%) and Explosion (17.3\%).

6. Coal-Fired Power Plant. As with General Heavy Industry, Pollution was by far $(78.8 \%)$ the principal risk associated with this facility.

7. Other. As would be expected, there was a wide variety of risks mentioned here, led by Pollution ( $36.6 \%$ ), Other (conglomerate category, 19.5\%) and Explosion (14.6\%).

8. LNG/LPG Storage, etc. There was agreement here that the risks were dominated by Explosion (60.0\%), Leak of LNG $(20.0 \%)$ and Fire (14.3\%).

9. Research Facility. The primary concerns of those who selectd this facility were Leak of Radioactive Materials (32.1\%) and Leak of Toxic Materials (28.6\%).

10. Nuclear Weapons/Defense. The chief risks associated with this facility were Leak of Radioactive Materials (28.6\%), Nuclear Accident (23.8\%) and Explosion (14.3\%).

11. Don't know.

12. Power Plant (Unspecified). By far ( $75.0 \%$ ) the leading risk for this facility was Human Error. This suggests that the respondents may have been referring to nuclear power plants.

13. None.

14. Oil-Fired Power Plant. The small number of respondents who selected this facility were concerned with either Pollution $(75.0 \%)$ or Fire $(25.0 \%)$. 
The Total column of Table 8 indicates the relative frequency of each of the types of risk across all fourteen facilities. Clearly the two most frequent were Pollution (28.8\%) and Leak of Radioactive Materials (22.8\%), followed by Explosion (8.0\%), Leak of Toxic Materials (7.0\%), Nuclear Accident ( $5.9 \%)$, Heal th Effects (5.0\%), etc. The six most frequently combinations of facility and risk (exposure paths) found in Table 8 are:

Facility

1. Nuclear Power Plant

2. General Heavy Industry

3. Coal-Fired Power Plant

4. Nuclear Power Plant

5. Oil Refinery

6. LNG/LPG Storage, etc.
Risk

Leak of Radioactive Materials Pollution Pollution Nuclear Accident Pollution Explosion
$\%$ of total citations

For the sample of respondents in this study, then, the exposure path of greatest concern was the Leak of Radioactive Material from a Nuclear Power Plant. That hazard generated twice the concern of Pollution from general Heavy Industry. Note that the top six exposure paths include the three types of facilities used in selecting the Hazardous Facility Communities, Nuclear Power Plant, Coal-Fired Power Plant and LNG/LPG Storage.

As Table 9 shows, there was something less than complete agreement among groups on the distribution of risks across all facilities. The significant $x^{2}$ and the Cramer's $V$ indicate that types of risk were moderately related to groups. The strongest indication of this relationship resides in two comparisons between the Nuclear Engineers and the remaining groups. The Nuclear Engineers were highest in selecting 
TABLE 9

Type of Riak Areociated with the closest

llazard oun Facility. By Group

\begin{tabular}{|c|c|c|c|c|c|c|c|}
\hline \multirow[b]{2}{*}{ TYPE OF HISK } & \multicolumn{7}{|c|}{ GROUP } \\
\hline & $\begin{array}{l}\text { General } \\
\text { Commun itie: } \\
x\end{array}$ & $\begin{array}{l}\text { Facilltios } \\
\text { Communitied } \\
x\end{array}$ & $\begin{array}{l}\text { Environ- } \\
\text { mentaliats } \\
x\end{array}$ & $\begin{array}{c}\text { Science } \\
\text { Uritere } \\
\mathbf{x}\end{array}$ & $\begin{array}{c}\text { Chemical } \\
\text { Engineers } \\
x\end{array}$ & $\begin{array}{l}\text { Muclear } \\
\text { Engineers } \\
x\end{array}$ & $\begin{array}{c}\text { Total } \\
x\end{array}$ \\
\hline Pollution (Contamination) & 28.0 & 28.5 & 26.8 & 27.3 & 32.4 & 46.6 & 30.1 \\
\hline leak of hadioactive Materiala & 11.2 & 31.4 & 23.8 & 25.6 & 17.6 & 9.6 & 22.7 \\
\hline Explosion & 11.5 & 10.1 & 7.9 & 4.5 & 7.4 & 8.2 & 9.0 \\
\hline Leak of Toxic Materials & 7.6 & 3.9 & 6.7 & 6.1 & 13.2 & 11.0 & 3.1 \\
\hline Muclear. Accident & 2.5 & 5.3 & 9.8 & 9.1 & 4.4 & 4.1 & 5.9 \\
\hline Heal th effects & 6.4 & 2.4 & 7.3 & 3.0 & 8.8 & 2.7 & 5.0 \\
\hline Fire & 1.0 & 2.9 & 3.7 & 3.0 & 2.9 & 5.5 & 4.2 \\
\hline Don't Know & 1.0 & 1.9 & 0.6 & 7.6 & 4.4 & 4.1 & 3.7 \\
\hline other & 5.1 & 1.4 & 5.5 & 4.5 & 2.9 & 1.4 & 3.5 \\
\hline None & 4.5 & 4.8 & 0.6 & 0.0 & 1.5 & 2.7 & 2.9 \\
\hline liuman Error & 0.0 & 1.0 & 1.8 & 1.5 & 4.4 & 2.7 & 1.5 \\
\hline Leak of I.MG & 1.3 & 3.4 & 1.2 & 1.5 & $\mathbf{0 . 0}$ & $\mathbf{0 . 0}$ & 1.6 \\
\hline Transportation Accident & 1.3 & 1.4 & 2.4 & 1.5 & 0.0 & 1.4 & 1.5 \\
\hline Huclear Core Meltdown & 0.6 & 1.4 & 1.8 & 3.0 & 0.0 & $\mathbf{0 . 0}$ & 1.2 \\
\hline Cenetic Effecta & 0.0 & 0.0 & 0.0 & 1.5 & $\mathbf{0 . 0}$ & $\mathbf{0 . 0}$ & 0.1 \\
\hline
\end{tabular}

$x_{(70)}^{2}=117.51 ; p<.001$

Cramer's $v=0,18$ 
Pollution ( $46.6 \%$ ) but lowest in selecting Leak of Radioactive Materials (9.6\%). This result follows from data presented in Table 7: Nuclear Engineers were highest in selecting both General Heavy Industry (21.6\%) and Coal-Fired Power Plant (18.9\%) as being the closest hazardous facility; they were lowest $(8.1 \%)$ in selecting Nuclear Power Plant. Item 非. The final item referring the the "closest hazardous facility that concerns you" asked respondents, "What persons are placed at risk by this facility?" In contrast to items $\# 2$ and $\# 3$, the coding scherne for the responses to this item was not based entirely on a sample of respondents' free responses but on those responses plus a preconceived set of categories. The set consisted of three mutually exclusive and exhaustive risk categories which together included all persons who may possibly have been placed at risk by a hazardous facility: a) Short-term public risk, b) Long-term public risk and c) Occupational risk. These three risk categories have been included in previous studies (Maynard, et al., 1976) as well as in other tasks in the questionnaire presented to these respondents. The use of these categories in the present task thus produces the added benefit of allowing comparisons to be made between these results and those from other tasks. The three risk categories were slightly modified for use here, and defined as follows:

Short-term public. Includes persons living at the time the hazard is produced. Does not include persons working at the facility or specifically identified public subgroups, such as those who are sick, pregnant, old, etc.

Long-term public. Includes persons not living at the time the hazard is produced. Excludes the same groups as in Short-term public. 
Occupational. Includes persons working at the facility.

In addition to these three categories, the sample of responses demonstrated the need for an additional six:

Short-term public and Long-term public. A simple combination of the two groups.

Short-term public and Occupational. Again, a simple combination of the two groups.

Specific groups of persons. Includes specifically identified public subgroups such as those who are sick, pregnant, old, etc. Everyone. Responses were coded into this category when either all three of the basic categories (Short-term public, Long-term public and Occupational) or the word Everyone was used.

No one. Either the term no one was used or the words used implied that no one would be placed at risk.

Don't know. Used when the response expressed a lack of knowledge regarding who might be placed at risk.

Table 10 shows the fourteen facilities crossed with the nine risk categories. Rather than analyze the entries in Table 10 which contain many empty cells, a reduced table, Table 11, was constructed. Table 11 consists of the six more frequently used risk categories crossed with the six more frequently selected hazardous facilities. The significant $x^{2}$ for Table 11 indicates that facilities and risk categories were related. The nature of this relationship can best be understood through identification in the table of cell entries that were statistically unexpectedly either high or low. This is done individually for each facility. 


\section{TABIE 10}

Persons Placed at Risk by life Closest Hazardous facility

\begin{tabular}{|c|c|c|c|c|c|c|c|c|c|c|c|}
\hline \multirow[b]{2}{*}{ FACILITY } & \multirow{2}{*}{ Short } & \multirow{2}{*}{$\frac{\text { Term Public }}{x}$} & \multirow{2}{*}{ Long } & \multicolumn{2}{|c|}{ Term Public } & \multicolumn{2}{|c|}{$\begin{array}{l}\text { RISK CATECOKY } \\
\text { Occupational }\end{array}$} & \multicolumn{2}{|c|}{$\begin{array}{l}\text { Short Terin Public } \\
\text { and } \\
\text { Long Term Public }\end{array}$} & \multicolumn{2}{|c|}{$\begin{array}{l}\text { Sliort Term Public } \\
\text { and } \\
\text { Occupalional }\end{array}$} \\
\hline & & & & $\mathbf{z}$ & & $\mathbf{N}$ & $\mathbf{z}$ & $\mathbf{N}$ & $\mathbf{z}$ & $N$ & $x$ \\
\hline Huclear Power Plant & 109 & 43.8 & $\mathbf{I}$ & 0.4 & & 11 & 4.4 & 1 & 0.4 & 76 & 30.5 \\
\hline General lleavy Indusiry & 45 & 44.1 & 0 & 0.0 & & 6 & 5.9 & $\mathbf{0}$ & 0.0 & 31 & 30.4 \\
\hline Chenical Production & 31 & 51.7 & $\mathbf{0}$ & 0.0 & & 6 & 10.0 & $\mathbf{0}$ & 0.0 & 15 & 25.0 \\
\hline Waste diaposal Facility & 28 & 52.8 & $\mathbf{0}$ & 0.0 & & 2 & 3.8 & 2 & 3.8 & 12 & 22.6 \\
\hline Dil Refinery/Petrochemical & 20 & 38.5 & $\mathbf{n}$ & 0.0 & & 6 & 11.5 & 0 & 0.0 & 21 & 40.4 \\
\hline Coal-pired Power Plant & 27 & 51.9 & $\mathbf{0}$ & 0.0 & & 1 & 1.9 & $\mathbf{0}$ & 0.0 & 9 & 17.3 \\
\hline ollier & 22 & 56.4 & $\mathbf{0}$ & 0.0 & & 3 & 7.7 & $\mathbf{0}$ & 0.0 & 7 & 17.9 \\
\hline I.NG/LPC Slorage, ElC. & 22 & 62.9 & $\mathbf{0}$ & 0.0 & - & $\mathbf{0}$ & 0.0 & 0 & 0.0 & 13 & 37.1 \\
\hline Research Facility & 5 & 17.9 & $\mathbf{0}$ & 0.0 & & 5 & 17.9 & $\mathbf{0}$ & 0.0 & 14 & 50.0 \\
\hline Nuclear Weapons/Defense & 9 & 45.0 & $\mathbf{0}$ & 0.0 & & 2 & 10.0 & $\mathbf{0}$ & 0.0 & 8 & 40.0 \\
\hline Don't know & 2 & 12.5 & $\mathbf{0}$ & 0.0 & & 0 & 0.0 & $\mathbf{0}$ & 0.0 & $\mathbf{0}$ & 0.0 \\
\hline Power llant (tuspecified) & 8 & 66.7 & $\mathbf{0}$ & 0.0 & & $\mathbf{0}$ & 0.0 & $\mathbf{0}$ & 0.0 & $\mathbf{1}$ & 8.3 \\
\hline None & $\mathbf{0}$ & 0.0 & 0 & 0.0 & & 1 & 11.1 & $\mathbf{0}$ & 0.0 & 0 & 0.0 \\
\hline oil-fired Power Plant & 2 & 50.0 & 0 & 0.0 & & $\mathbf{0}$ & 0.0 & 0 & 0.0 & $\mathbf{0}$ & 0.0 \\
\hline TOTAL. & 330 & 45.1 & 1 & 0.1 & & 43 & 5.9 & 3 & 0.4 & 207 & 28.3 \\
\hline
\end{tabular}


TABI.E 10 (continned)

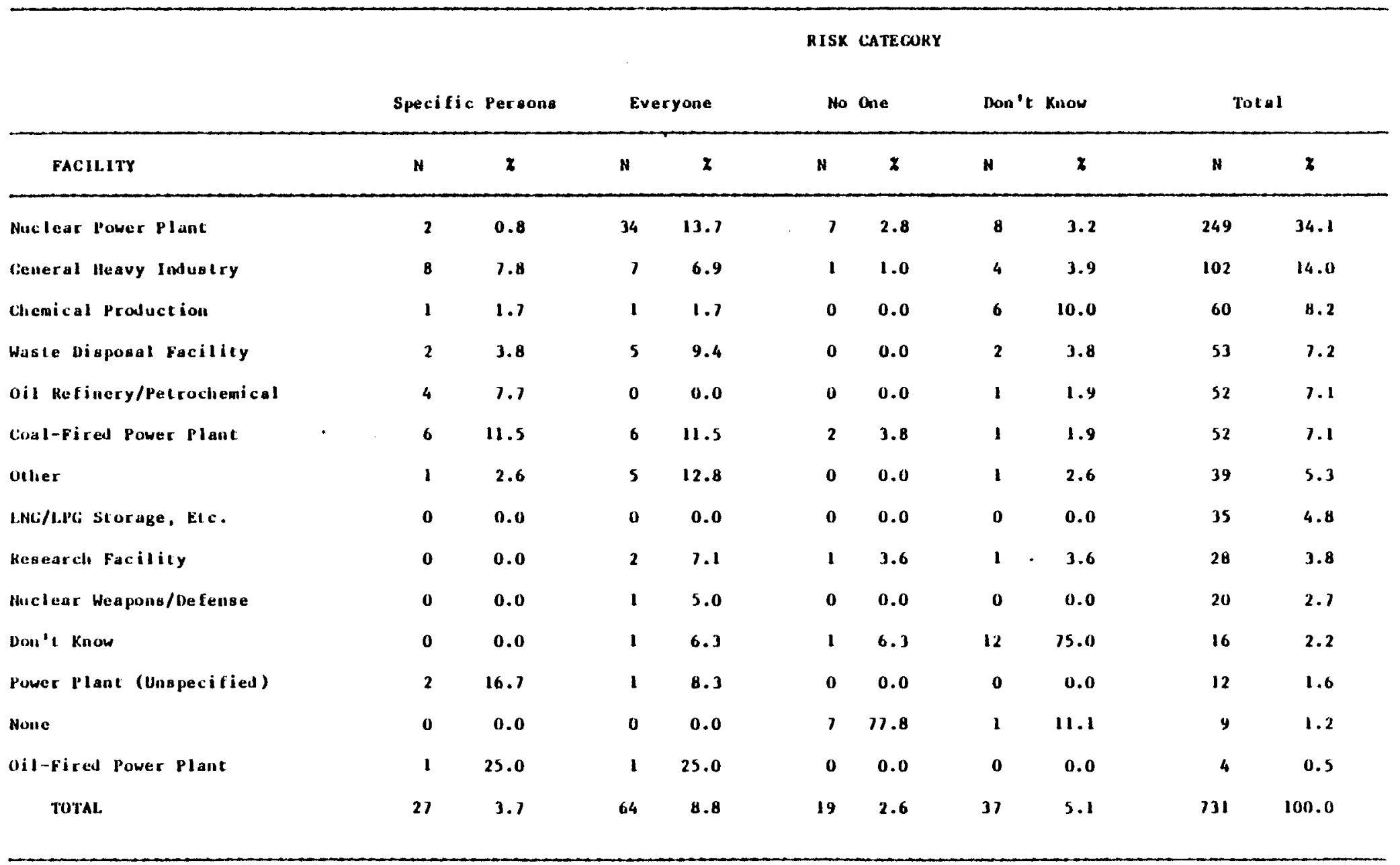


TABLE 11

The Six More Frequently Used Rigk Categories, by the Six More Frequently Selected llazardaus Facilities

\begin{tabular}{|c|c|c|c|c|c|c|c|}
\hline FACILITY & Short-Terth Public & $\begin{array}{l}\text { Short-Teru Public } \\
\text { and Oecupational }\end{array}$ & Everyone & Occupational & $\begin{array}{l}\text { Specific Groups } \\
\text { of Persons }\end{array}$ & Don't Know & Tulal \\
\hline Nuclear Power Plant & 109 & 76 & 34 & 11 & 2 & 8 & 240 \\
\hline General lleavy Industry & 45 & 31 & 7 & 6 & 8 & 4 & 101 \\
\hline Chemical Production & 31 & 15 & 1 & 6 & $\mathbf{t}$ & 6 & 60 \\
\hline Wasle disposal Facility & 28 & 12 & 5 & 2 & 2 & 2 & 51 \\
\hline oil Refinery/Petrochemical & 20 & 21 & $\mathbf{0}$ & 6 & 4 & 1 & 52 \\
\hline Coal-Fired Puwer Plant & 27 & 9 & 6 & 1 & 6 & 6 & 50 \\
\hline TOTAl. & 260 & 164 & 53 & 32 & 23 & 22 & 554 \\
\hline
\end{tabular}

$$
x_{(25)}^{2}=57.61 ; p<.001
$$


Nuclear Power Plant. This facility was high on the Everyone category and low on the Specific Groups of Persons category.

General Heavy Industry. Hign on Specific Groups of Persons. Chemical Production. High on Don't Know, low on Everyone.

Waste Disposal Facility. (No significant deviations.)

Oil Refinery/Petrochemical. High on Occupational and for Specific Groups of Persons, low on Everyone.

Coal-Fired Power Plant. High on Specific Groups of Persons, low on Short-term public and Occupational.

From this summary it can be seen that the two most important risk categories discriminating among the facilities were Everyone and Specific Groups of Persons. Nuclear Power Plant was the only facility that was high for Everyone and the only facility that was low for Specific Persons. All of the remaining facilities except Waste Disposal Facility were either low for Everyone, high for Specific Persons or both. The major distinction was between Nuclear Power Plant and the remaining facilities, the former being associated with pervasive risks, including risks to future generations. Other facilities were generally associated with risks affecting specific groups of particularly vulnerable living persons. Within individual facilities, there were no significant correlations between groups and risk categories.

Table 10 contains an important result in the Total row. The entries in this row indicate the relative frequency of use by all respondents, across all facilities, of the nine risk categories. 
2. Short-term Public \& Occupational 28.3

3. Everyone 8.8

4. Occupational 5.9

5. Don't know 5.1

6. Specific Groups of Persons 3.7

7. No One 2.6

8. Short-term Public \& Long-term Public 0.4

9. Long-term Public 0.1

The significance of these data lies in the relatively infrequent use by respondents of risk categories that referred in any way to Long-term Public risk, i.e., categories 3,8 and 9 above. Of all the risk categories that referred to any group of persons (i.e., excluding the Don't know and No One categories), the categories that included reference to Long-term Public risk account for only $10.1 \%$ of the total. Categories referring only to presently living persons (numbers $1,2,4$ and 6 above) account for the remaining $89.9 \%$. Thus, the respondents in this study, in a situation where they were unprompted and free to nominate any group of persons as being placed at risk by a hazardous facility, overwhelmingly thought of living members of the present generation rather than members of future generations. Moreover, of all the categories that referred in any way to Long-term Public risk, only $1.5 \%$ of the total referred to Long-term Public risk alone. The remaining $98.5 \%$ included Long-term Public risk with other risk categories, (i.e., in Everyone, and in Short-term Public risk and Long-term Public risk, combined).

Table 12 shows how each of the six groups of respondents distributed their uses of the risk categories. The significant $\chi^{2}$ and the Cramer's $V$ indicate that groups and risk categories were moderately related. The 
TABLE 12

Percentage of Meapondent. Who Identified a civen category

of Peraons as Being Placed at Rigk by Cloweot llazardoue Facillity, By Group

\begin{tabular}{|c|c|c|c|c|c|c|c|}
\hline RISK CATEGORY & $\begin{array}{l}\text { General } \\
\text { Commun it ifes } \\
\text { (N-154) }\end{array}$ & $\begin{array}{l}\text { Hazard ous } \\
\text { Facilities } \\
\text { Commenities } \\
\text { (N-204) }\end{array}$ & $\begin{array}{l}\text { Enviran- } \\
\text { mentaliots } \\
(N=163)\end{array}$ & $\begin{array}{l}\text { ROUP } \\
\text { Science } \\
\text { Writers } \\
(N=67)\end{array}$ & $\begin{array}{l}\text { Chemical } \\
\text { Engineer. } \\
(N-66)\end{array}$ & $\begin{array}{l}\text { Huclear } \\
\text { Englneere } \\
(\mathrm{N}-74)\end{array}$ & $\begin{array}{c}\text { Total } \\
(\mathrm{N}-733)\end{array}$ \\
\hline Short-Term Public & 36.5 & 51.5 & 52.8 & 34.3 & 42.4 & 40.5 & 45.0 \\
\hline Long-Tere Public & 0.0 & $\mathbf{0 . 0}$ & 0.6 & $\mathbf{0 . 0}$ & $\mathbf{0 . 0}$ & $\mathbf{0 . 0}$ & 0.1 \\
\hline Occupational & 8.2 & 6.9 & 0.6 & 6.0 & 1.6 & 8.1 & 5.9 \\
\hline Sliort- and Long-Terw Public & $\mathbf{0 . 0}$ & $\mathbf{0 . 0}$ & 1.8 & 0.0 & 0.0 & 0.0 & 0.4 \\
\hline Short-Term Public and Occupalional & 25.2 & 21.0 & 30.1 & 29.9 & 33.3 & 29.7 & 28.4 \\
\hline Speclfic Groups of Persone & 5.0 & 1.5 & 1.8 & 6.0 & 6.1 & 6.8 & 3.7 \\
\hline Everyoule & 12.6 & 4.4 & 9.8 & 17.9 & 3.0 & 8.1 & 8.9 \\
\hline No One & 3.1 & 4.4 & 0.6 & 0.0 & 1.5 & 4.1 & 2.6 \\
\hline Don't Ku.ow & 9.4 & 4.4 & 1.8 & 6.0 & 6.1 & 2.7 & 5.0 \\
\hline
\end{tabular}

Cramer's $v=0.15$ 
cell entries that were unexpectedly either high or low are listed below for each group.

General Communities. High on Don't know, low on Short-term Public.

Hazardous Facility Communities. High on Short-term Public risk, low on Everyone.

Environmentalists. High on Short-term Public risk, low on Occupational risk and Don't know.

Science Writers. High on Everyone, low on Short-term public risk.

Chemical Engineers. Low on Everyone.

Nuclear Engineers. (No significant deviations from the sample as a whole.)

This summary offers several interesting comparisons. The Hazardous Facility Communities differed from the General Communities, for example, primarily in their greater familiarity with the effects of hazardous facilities and their more frequent mention of those members of the public immediately affected as opposed to those who may be affected in the future. The Environmentalists differed similarly from the General Commities but in addition they frequently identified those who work at hazardous faclities. The Science Writers differed from the Environmentalists primarily in their more frequent nomination of all those affected by hazardous facilities, the contemporary public, workers and the future public, rather than only the contemporary public. The Chemical Engineers mentioned the total groups of persons affected by hazardous facilities less frequently than did Nuclear Engineers. 
Toxic chemical and nuclear waste disposal facilities. Unlike the first four items in the Hazardous Facilities section which referred to a hazardous facility selected by each individual respondent, the final four items referred to two specific types of facilities, a toxic chemical disposal facility and a nuclear waste disposal facility. All of the respondents thus provided risk perception information for the same facilities.

Item \#5. The first of two items referring to a toxic chemical disposal facility, asked respondents, "For you, what specific sorts of risk are associated with such a facility?" As with item 非, a sample of the respondents' free responses was examined, and ten risk categories were constructed. The remaining responses were individually coded as belonging to one of the ten categories. Table 13 shows the ten risk categories crossed with the six groups of respondents. Type of risk and groups were related, as indicated by a significant $\chi^{2}$ and a Craner's $V$ of 0.15. Each group is described below in terms of the cell entries that were unexpectedly either high or low.

General Communities. High on Health Effects, low on Pollution. Hazardous Facility Communities. High on None.

Environmentalists. High on Pollution, low on Leaks of Toxic Materials and None.

Science Writers. High on Heal th Effects, Low on Pollution. Chemical Engineers. High on Human Error and Genetic Effects, low on Health Effects.

Nuclear Engineers. High on Leaks of Toxic Materials, low on Heal th Effects. 


\section{TABLE 13}

Perceutage of Respondents Who Identified a Given Type

of Rlak as Being asociated with a Toxic Chemical biaposal Pacility, By Group

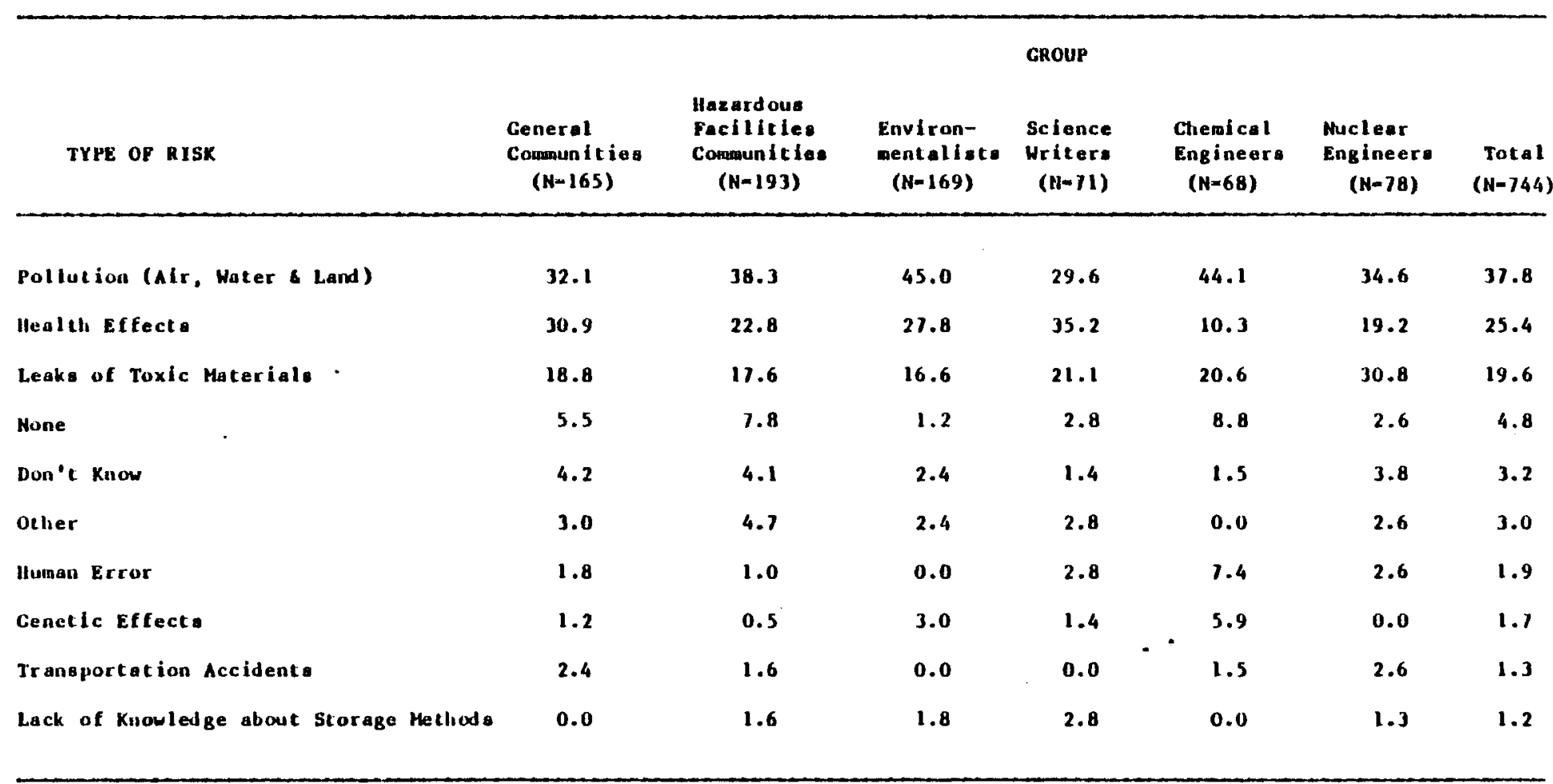

$x^{2}(45)=81.26 ; p^{<} .001$

Cramer': $v=0.15$ 
Interesting comparisons here include that between General and Hazardous Facility Communities; the former indicated greater concern for the ill effects of toxic wastes on human health, while the latter indicated greater belief in the lack of any ill effects. Compared with the General Communities, the Environmentalists more frequently indicated concern for environmental pollution from toxic wastes. The concerns of the Science Writers were similar to those of the General Communities. Human Error and Genetic Effects were of greater concern to the Chemical rather than the Nuclear Engineers; the latter tended to mention concern for Leaks of Toxic Materials.

Iter 非. The second of two items referring to a toxic chemical disposal facility, this item asked respondents, "In your opinion, what persons would be placed at risk by a toxic chemical disposal facility?" Respondents' free responses were coded according to the scheme used in item \#4 above. The results given in Table 14 show that groups of respondents and risk categories were moderately related. The unexpectedly high or low cell entries are described for each group in turn.

General Communities. High on Everyone.

Hazardous Facility Communities. High on Occupational risk, No One and Don't know, low on Short-term Public risk and Short-term Public and Occupational risk.

Environmentalists. High on Short-term Public risk, low on Occupational risk, Short-term Public and Occupational risk and None. Science Writers. High on Everyone, low on No One. 
TAHIE 14

Percentage of Resposwents Who Identified a Civen Type of Misk as Being Associated with a Foxtc Chemical Disposal facility. Hy Croup

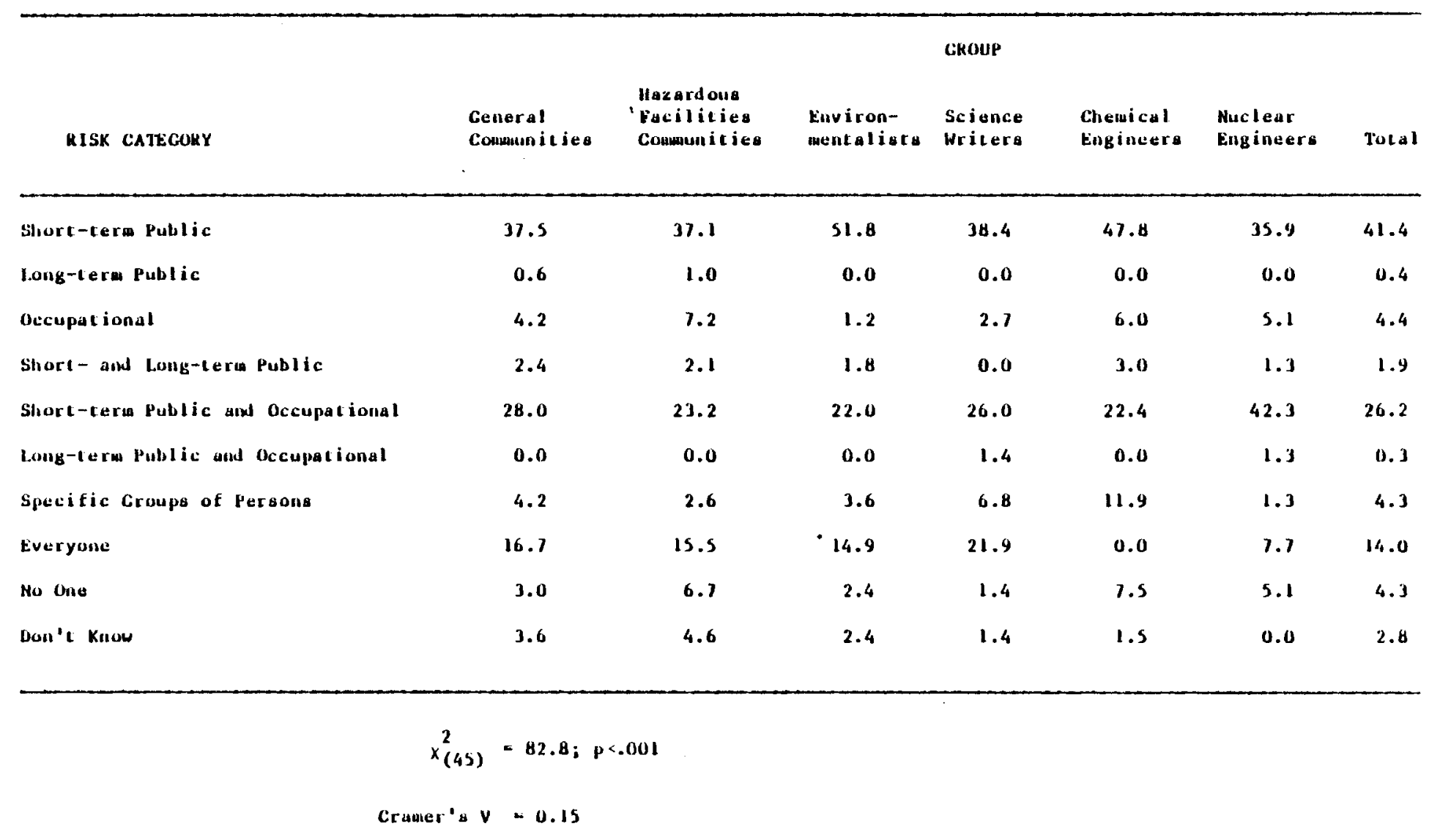


Chemical Engineers. High on Specific Groups of Persons and None, low on Everyone.

Nuclear Engineers. High on Short-term Public and Occupational risk, low on Everyone.

There is a notable difference between the belief of the General Communities that everyone is exposed to the hazard, on the one hand, and the belief of the Hazardous Facility Communities that exposure is confined primarily to workers at the facility. The Environmentalists differed from the two public groups most strongly in their concern for risks affecting the contemporary public, as opposed especially to risks affecting workers at the facility. Except for less frequently proposing that no one is affected by the facility, Science Writers were similar to General Commities. Chemical and Nuclear Engineers tended to agree that not everyone is affected by the facility. The Chemical Engineers tended to believe that only specific groups of persons would be exposed to risks, while the Nuclear Engineers indicated concern for both the contemporary public and workers at the facility.

Item 非. The first of two items referring to a nuclear waste disposal facility, this item asked respondents, "For you, what specific sorts of risks are associated with such a facility?" Respondents' free responses were coded according to the scheme used in item $\$ 5$ above. Types of risk are crosstabulated with groups of respondents in Table 15. The significant $x^{2}$ and the Cramer's $V$ of 0.15 indicate a moderate relationship between risk types and groups. The six groups of respondents are described below in terms of the cell entries that were unexpectedly either high or low. 
TABLE 15

Percentage of Reapondents Who Identified Given Type of Risk as Being Aasociated with a Nuclear Wate Dispasal Facility. By Group

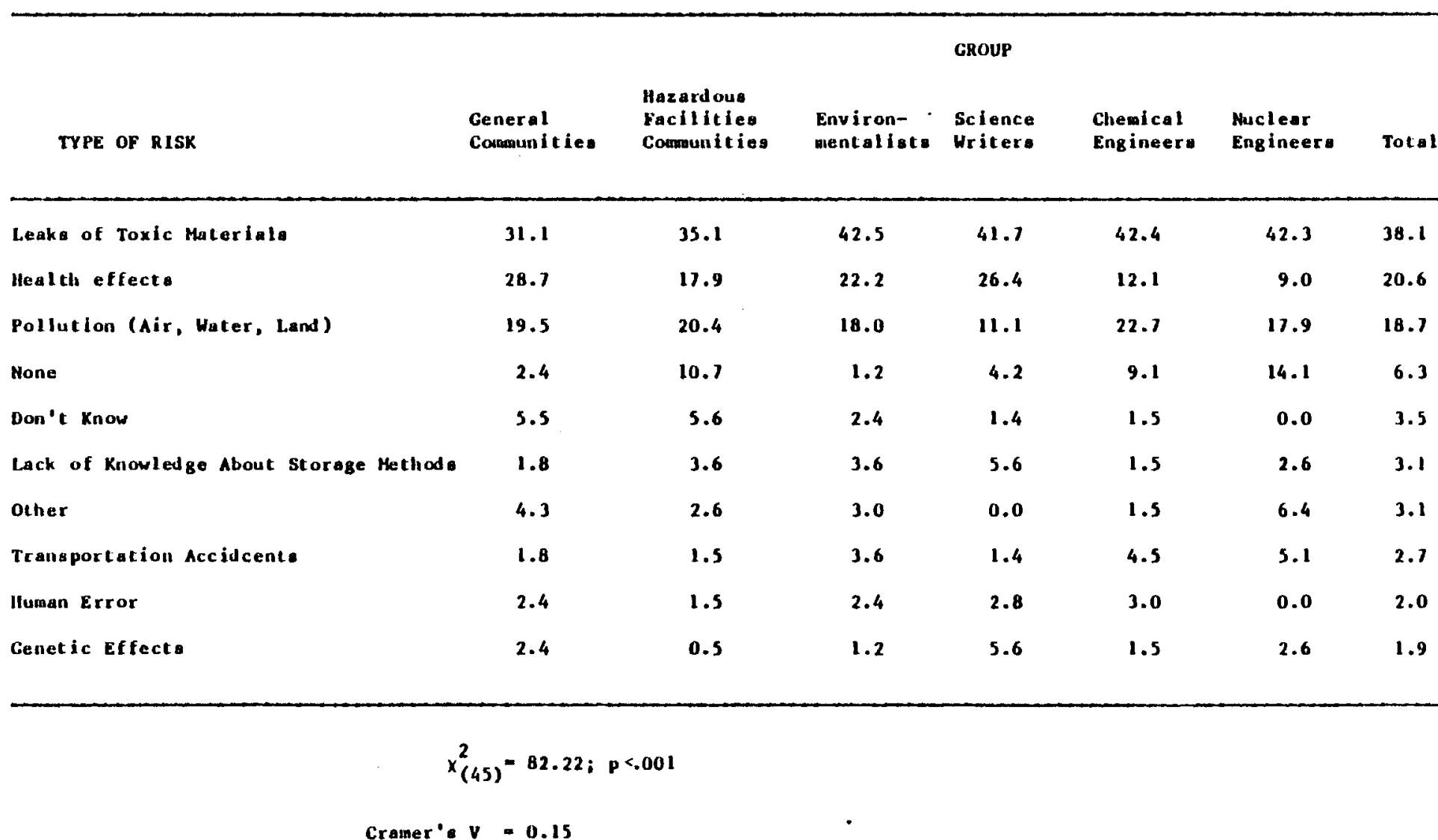


General Communities. High on Health Effects and Don't Know, low on None.

Hazardous Facility Communities. High on None and Don't know, low on Genetic Effects.

Environmentalists. Low on None and Don't Know.

Science Writers. High on Genetic Effects and Lack of Knowledge, low on Pollution, None and Don't Know.

Chemical Engineers. High on None, low on Health Effects and Don't know.

Nuclear Engineers. High on None, Others and Transportation Accidents, low on Health Effects, Don't Know and Human Error. The most telling contrasts for this item involve the categories None and Don't know. Al though the two public groups were high on Don't know, the four established groups were low. This result is consistent with expected differential levels of expertise between the two sets of groups. For the None category, however, the arrangement of groups was different. Few of the members of the General Communities, Environmentalists or Science Writers groups responded that the risks were None. Many more in the Hazardous Facility Communities, the Chemical Engineers and the Nuclear Engineers used this category. This result reflects respondents' beliefs about the risks associated with nuclear wastes. Those who tended more to be less closely linked by geography or profession to industrial technology (General Communities, Environmentalists and Science Writers) provided little support for the proposition that nuclear wastes presented no risks; those who tended more to be more involved by geography or profession (Hazardous Facility 
Comranities, Chemical Engineers and Nuclear Engineers) did support that proposition. It is of particular interest with regard to nuclear wastes to examine the choices of the Nuclear Engineers. In addition to their positions on the Don't know and None categories, their low frequency of mention of the Health Effects and Human Error categories indicates a belief that the risks of nuclear wastes are at least manageable. On the other hand, their high standings on other and Transportation Accidents suggests insiders' knowledge of potential hazards unfamiliar to the general public.

Item 非8. The final item in this section and the second of two items referring to a nuclear waste disposal facility, this itern asked respondents, "In your opinion, what persons would be placed at $r$ isk by a nuclear waste disposal facility?" Respondents' free responses were coded according to the scheme used in items $\$$ 非 and $\neq$ f6 above. The results shown in Table 16 indicate a moderately strong relationship between risk categories and groups. The unexpectedly high or low entries are described for each group in turn.

General Communities. High on Everyone, low on Occupational. Hazardous Facility Communities. High on Occupational risk and Don't know, low on Everyone.

Environmentalists. High on Long-term Public risk, Short-term and Long-term Public risk and Everyone, low on Occupational risk and No One.

Science Writers. High on Everyone, low on Occupational risk, No One and Don't know. 


\section{TABLE 16}

Percentage of Reapondent: Who Identified a Civen Category of

Permone as Being at kiok from a Nuclear Haste Disposal Fachlity, By Croup

\begin{tabular}{|c|c|c|c|c|c|c|c|}
\hline & & & & GROUP & & & \\
\hline RISK CATEGORY & $\begin{array}{l}\text { Ceneral } \\
\text { Comanunities } \\
\text { (N+168) }\end{array}$ & $\begin{array}{l}\text { Facilitiee } \\
\text { Communities } \\
(N-193\end{array}$ & $\begin{array}{l}\text { Environ- } \\
\text { mental iste } \\
(N=165)\end{array}$ & $\begin{array}{r}\text { Science } \\
\text { Writers } \\
(N-72)\end{array}$ & $\begin{array}{l}\text { Chemical } \\
\text { Engineers } \\
(N=66)\end{array}$ & $\begin{array}{l}\text { Huclear } \\
\text { Engincers } \\
(N-79)\end{array}$ & $\begin{array}{c}\text { Total } \\
(\mathrm{N}-743)\end{array}$ \\
\hline Short-term Public & 29.2 & 34.2 & 32.1 & 23.6 & 36.4 & 24.1 & 30.7 \\
\hline Long-term Public & 2.4 & 1.0 & 4.2 & 1.4 & 0.0 & 2.5 & 2.2 \\
\hline Occupational & 3.6 & 9.8 & 1.2 & 2.8 & 4.5 & 19.0 & 6.3 \\
\hline Short- and Long-term Public & 3.6 & 3.1 & 7.9 & 4.2 & 9.1 & .1 .3 & 4.7 \\
\hline Short-term Public and Occupational & 25.6 & 21.0 & 21.8 & 36.1 & 30.3 & 30.4 & 25.7 \\
\hline Long-term Public and Occupational & 0.0 & 0.5 & 0.6 & 0.0 & 0.0 & $\mathbf{0 . 0}$ & $\mathbf{0 . 3}$ \\
\hline Specific Groups of Persons & 1.8 & 2.1 & 0.6 & 4.2 & 6.1 & 0.0 & 2.0 \\
\hline Everyone & 28.0 & 17.6 & 27.3 & 25.0 & 4.5 & 6.3 & 20.5 \\
\hline No onse & 3.6 & 5.7 & 2.4 & 2.8 & 7.6 & 16.5 & 5.5 \\
\hline Don't know & 2.4 & 4.1 & 1.8 & 0.0 & 1.5 & 0.0 & 2.2 \\
\hline
\end{tabular}

$$
x_{(45)}^{2}=12.61 ; p<.001
$$

Cramer'v $V=0.19$ 
Chemical Engineers. High on Short-term and Long-term Public risk and Specific Groups of Persons, low on Everyone.

Nuclear Engineers. High on Occupational risk and No One, low on Short-term and Long-term Public risk, Specific Groups of Persons and Everyone.

The contrasts among the groups are clearly seen on several risk categories. For example, on Occupational risk the General Communities, the Environmentalists and the Science Writers were low, while the Hazardous Facility Communities and Nuclear Engineers were high. Those more closely associated with the facility (Hazardous Facility Communities and Nuclear Engineers) were more concerned about the workers--those most closely associated with the facility. The groups that were low on the Occupational risk category were high on Everybody, and those that were high on Occupational were low on Everybody. Respondents not geographically or professionally linked to the facility thus indicated greater concern for persons similarly distant from the technology (including those most distant, future generations). Respondents more closely connected with the facility by geography or profession indicated greater concern for persons similarly close to the facility. Another contrast of interest is the relatively frequent use of the Long-term Public risk category by the Environmentalists, an indication of the ir beliefs about the long range effects of zadioactive materials. Finally, the Nuclear Engineers were the only group that was high on No One, an indication, perhaps, of their confidence in their abilities to control the hazards of nuclear wastes. Both the Environmentalists and the 
Science Writers indicated that they did not share the Nuclear Engineers' confidence.

Toxic chemical us. nuclear wastes. Differences between respondents' overall risk beliefs for a toxic chemical disposal facility and their risk beliefs for a nuclear waste disposal facility can be highlighted by comparing the Total columns of Tables 13,14,15 and 16. A comparison between the total columns of Tables 13 and 15 reveals significant differences between the types of risk associated by all respondents with a toxic chemical disposal facility (TCDF) as opposed to those associated with a nuclear waste disposal facility (NWDF) $\left(X_{(9)}^{2}=108.0 ; p<.001\right)$. The two facilities differed strongly on four of the ten types of risk: Toxic chemical disposal facility. High on Pollution, low on Leak of Toxic Materials, Transportation Accidents and Lack of Knowledge.

Nuclear waste disposal facility. High on Leaks of Toxic Materials, Transportation Accidents and Lack of Knowledge, low on Pollution.

Since Pollution and Leaks of Toxic Materials together accounted for $57.1 \%$ of all the risk choices made by respondents, as opposed to $4.2 \%$ accounted for by Transportation Accidents and Lack of Knowledge, the former represent the two types of risk that most strongly separated a TCDF from a NWDF. A TCDF was more closely associated with Pollution, while a NWDF was more closely associated with Leaks of Toxic Materials.

A comparison between the Total columns of Tables 14 and 16 shows that there were significant differences between the categories of persons identified by respondents as being placed at risk by a TCDF and those 
placed at risk by a NWDF. $\left(x_{(9)}^{2}=48.0 ; p<.001.\right)$ The two facilities differed substantially on five of the ten categories of risk:

Toxic chemical disposal facility. High on Short-term Public risk and Specific Groups of Persons, low on Long-term Public risk, Short-term and Long-term Public risk, and Everyone.

Nuclear waste disposal facility. High on Long-term Public risk, Short-term and Long-term Public risk and Everyone, low on Short-term Public risk and Specific Groups of Persons.

The primary difference between respondents' perceptions of a TCDF and a NWDF is clear. Each of the risk categories more strongly associated with a TCDF consisted solely of risks affecting the contemporary public. In - contrast, each of the risk categories more strongly associated with a NWDF included risks affecting future generations; in addition, one of the risk categories also included Short-term Public risk, another both Short-term Public risk and Occupational risk.

Taken together, these two contrasts between $a \mathrm{TCDF}$ and a NWDF, one based on type of risk, the other on the persons placed at risk, show that respondents viewed a TCDF as being more closely associated with Pollution affecting the contemporary public and a NWDF as being more closely associated with Leaks of Toxic Materials (leaks of radioactive materials) affecting everyone, including future generations, the contemporary public and workers.

\section{$\underline{\text { Summary }}$}

In departure from typical practice in studies of public risk perception, free response items were used in order to identify categories 
of risk perception "in the raw," relatively unaffected by the investigators' expectations. The task included eight items, four referring to "the closest hazardous facility that concerns you" and two each referring to a toxic chemical disposal facility and a nuclear waste disposal facility.

The first of the four "closest hazardous facility" items asked respondents how near it was to where they lived. Respondents were free to define any facility as being hazardous. Almost half (49.5\%) of the respondents identified a hazardous facility within ten miles; $14 \%$ identified no hazardous facility within fifty miles. The Hazardous Facility Communities group reported hazardous facilities much closer to them than did the other groups.

The second item asked what sort of hazardous facility the closest one was. A nuclear power plant was the most frequently identified facility ( $34 \%$ of all respondents); this was true for all groups except the Nuclear Engineers. Respondents who named facilities in the categories of Chemical Production, Coal-fired Power Plant and General Heavy Industry tended to report smaller distances than those who mentioned a Nuclear Power Plant or a Waste Disposal Facility. Residents of Hazardous Facility Communities reported living closer than other groups to the facilities that were, in fact, closer to their homes.

The third item asked what types of risk were associated with the facility. The two most frequently nominated risks overall were Pollution (28.6\%) and Leak of Radioactive Materials (22.8\%); types of risk varied greatly with types of facility. The most frequently mentioned exposure path was a Leak of Radioactive Material from a Nuclear Power Plant 
(20.0\% of all combinations). Types of risk mentioned were moderately related to (i.e., differed as a function of) respondent groups.

The fourth and final item in this series asked what persons would be placed at risk. Respondents produced a strong contrast between Nuclear Power Plant (associated to a greater extent with pervasive risks, including risks to future generations) and the other hazardous facilities (associated to a greater extent with risks affecting specific groups of particularly vuinerable persons). Relatively little mention was given by respondents to concerns for members of future generations; categories referring in any way to future generations accounted for only $10.1 \%$ of the total selections.

The first of the two toxic chemical disposal facility (TCDF) items asked what types of risks were associated with such a facility. The second item asked what persons were affected by the risks. Results for these items showed strong differences in risk perception among groups of respondents. The two nuclear waste disposal facility (NWDF) items were similar to those used for the TCDF and also produced strong group differences. With the NWDF, for example, respondents from General Communities, Environmentalists and Science Writers rarely suggested that the NWDF presented no risks; other respondents more closely related to industrial technology by geography or profession (Hazardous Facility Commities, Chemical Engineers and Nuclear Engineers) did. Also with the NWDF, respondents more removed from the facility (General Communities, Environmentalists and Science Writers) indicated greater concern for persons similarly removed from the technology (including those most distant, future generations); respondents more closely 
connected with the facility (Hazardous Facility Communities and Nuclear Engineers) indicated greater concern for persons similarly related to the facility.

Respondents to the two TCDF and the two NWDF items produced a strong and clear contrast between the two facilities: a TCDF was seen as being more closely associated with pollution affecting the contemporary public, while a NWDF was seen as being more closely associated with leaks of toxic materials affecting everyone, including future generations, the contemporary public and workers at the facility.

Finally, summaries of the differences among the groups of respondents are presented in Tables 17 and 18. Entries in these tables consist of the categories on which each of the groups was relatively either high or low for each of the facilities included in the task, the "closest hazardous facility," the TCDF and the NWDF. These categories are the ones that distinguished the groups from one another. Presented in Table 17 are the categories of types of risk that received either relatively high or low use. Only two of the three types of facilities are included here because the third, the "closest hazardous facility," was coded in categories different from those used for the others. In order to clarify the group differences, the far right hand column of Table 17 lists the categories that were common to the two facilities for each group. Thus, we see that what most distinguished the General Communities was their greater mention of Health Effects. In contrast, the two groups of Engineers were distinguished by their infrequent mention of Health Effects. Similarly, the Hazardous Facility Communities 
TABLE 17

Categorieg of Typen of Riak that Received Efther Helatively lligh or low the, ly Factlity

\begin{tabular}{|c|c|c|c|c|}
\hline \multirow[t]{2}{*}{ CKOUP } & \multirow{2}{*}{$\begin{array}{l}\text { REL.ATIVE } \\
\text { POSITION }\end{array}$} & \multicolumn{3}{|c|}{ FACILITY } \\
\hline & & $\begin{array}{l}\text { Toxic Clienical } \\
\text { Disposal Facility }\end{array}$ & $\begin{array}{l}\text { Huclear Waste } \\
\text { visposal Facility }\end{array}$ & $\begin{array}{l}\text { Categorieg Comuon } \\
\text { to the Two Facilitieg }\end{array}$ \\
\hline \multirow[t]{2}{*}{ General Communitieg } & IIiglı & Health Effects & $\begin{array}{l}\text { Health Effecta: } \\
\text { Don't know }\end{array}$ & Health Effects \\
\hline & Low & Pollution & None & \\
\hline \multirow[t]{2}{*}{ Hazardous Facility Commonitied } & $\| i_{g h}$ & None & $\begin{array}{l}\text { None; } \\
\text { Don't know }\end{array}$ & Mone \\
\hline & Low & & Genetic Effecto & \\
\hline \multirow[t]{2}{*}{ Environmentaliats } & lligh & Pollution & & \\
\hline & L.ow & $\begin{array}{l}\text { Leak of Toxic Materialoi } \\
\text { None }\end{array}$ & $\begin{array}{l}\text { None; } \\
\text { Don't know }\end{array}$ & None \\
\hline \multirow[t]{2}{*}{ Science Writers } & High & Health Effects & $\begin{array}{l}\text { Genetic Effects; } \\
\text { Lack of Knowledge }\end{array}$ & \\
\hline & Low & Pollution & $\begin{array}{l}\text { Pollution; } \\
\text { Hone; Don't know }\end{array}$ & Pollution \\
\hline \multirow[t]{2}{*}{ Chemical Engineers } & lligh & $\begin{array}{l}\text { Iluman Error: } \\
\text { Genetic Effecto }\end{array}$ & None & \\
\hline & Low & Health Effects & $\begin{array}{l}\text { Health Effect a; } \\
\text { Don't Know }\end{array}$ & Health Effects \\
\hline \multirow[t]{2}{*}{ Nuclear Engineers } & Higll & Leak of Toxic Materials & $\begin{array}{l}\text { None; Other; } \\
\text { Transportation accidents }\end{array}$ & \\
\hline & Low & Itealth Effects & $\begin{array}{l}\text { Health Effects; } \\
\text { Don't Know; Uuman Error }\end{array}$ & llealth Effects \\
\hline
\end{tabular}


TABLF. 18

Categories of Persong Placed at Rick That Received Eitluer Relatively lligli or low Use, by Facility

\begin{tabular}{|c|c|c|c|c|c|}
\hline \multirow[t]{2}{*}{ GROUP } & \multirow{2}{*}{$\begin{array}{l}\text { RELATIVE } \\
\text { POSITION }\end{array}$} & \multicolumn{4}{|c|}{ FACILITY } \\
\hline & & $\begin{array}{c}\text { Closeat Haxardous } \\
\text { Facility }\end{array}$ & $\begin{array}{l}\text { Toxic Chemical } \\
\text { Dieposal racility }\end{array}$ & $\begin{array}{l}\text { Muclear Hacte } \\
\text { Disposal facilicy }\end{array}$ & $\begin{array}{l}\text { Categories Coamon To } \\
\text { at Least Two Facilitiea }\end{array}$ \\
\hline Coneral communiried & $\begin{array}{l}\text { High" } \\
\text { Low }\end{array}$ & $\begin{array}{l}\text { Dan't Know } \\
\text { Short-Term Public (STr) }\end{array}$ & Everyone & $\begin{array}{l}\text { Everyone } \\
\text { Occupational }\end{array}$ & Everyone \\
\hline \multirow[t]{2}{*}{ Hiazurdans Facility Communitires } & $\| i_{g h}$ & ste & $\begin{array}{l}\text { Occupational: No One; } \\
\text { Don't Know }\end{array}$ & $\begin{array}{l}\text { Occupational, } \\
\text { Don't Know }\end{array}$ & $\begin{array}{l}\text { Occupational: } \\
\text { Don't Know }\end{array}$ \\
\hline & Low & Everyone & STP: STP Occupational & Everyone. & Everyone \\
\hline \multirow[t]{2}{*}{ Denvironumentalists } & $\| \mathbf{l i g h}$ & stp & strp & $\begin{array}{l}\text { Long-Term Public (L.TP); } \\
\text { STP \& LTP; Everyone }\end{array}$ & STP \\
\hline & Low & $\begin{array}{l}\text { Dccupat lonal: } \\
\text { Don't know }\end{array}$ & $\begin{array}{l}\text { Occupational; } \\
\text { STP \& Occupational; } \\
\text { No One }\end{array}$ & $\begin{array}{l}\text { Occupational } \\
\text { No One }\end{array}$ & $\begin{array}{l}\text { Occupational; } \\
\text { No One }\end{array}$ \\
\hline \multirow[t]{2}{*}{ Science Writera } & $\mathbf{H I}_{\mathbf{g h}}$ & Everyone & Everyone & Everyone & Everyone \\
\hline & Low & sTr & No One & $\begin{array}{l}\text { Occupational; No One; } \\
\text { Don't Know }\end{array}$ & No One \\
\hline \multirow[t]{2}{*}{ Chemical Engineers } & Higlı & & Specific Groups; None & $\begin{array}{l}\text { STP; LTP; } \\
\text { Gpecific Groups }\end{array}$ & Specific Croups \\
\hline & Low & Everyone & Everyons & Everyone & Everyane \\
\hline \multirow[t]{2}{*}{ Nuclear Engineer } & High & & $\begin{array}{l}\text { STP: } \\
\text { Dccupational }\end{array}$ & Oscupational; No One & Occupational \\
\hline & Low & & Everyono & $\begin{array}{l}\text { STP \& LTP, Evaryone: } \\
\text { Speclfic Groups }\end{array}$ & Evaryane \\
\hline
\end{tabular}


were high on None (i.e., no hazardous effects), while the Environmentalists were low.

Table 18 presents the categories of persons placed at risk that received either relatively high or low use. All three types of facilities are described in terms of their common coding scheme. The far right hand column of Table 18, as in the previous table, 1 ists the categories that were common to at least two facilities for each group. Here we see that the General Commuties and the Science Writers shared a high use of Everyone, while the Hazardous Facility Communities and the two groups of Engineers shared a low use. The Hazardous Facility Communities were high on Occupational Risk; the Environmentalists were 1ow. Both the Environmentalists and the Science Writers agreed in giving the No One category little use. In general, then, those respondents (Hazardous Facility Commities, Chemical Engineers and Nuclear Engineers) most closely associated with hazardous facilities either by geography or profession tended to distinguish themsalves by their concern for specific groups of living persons, particularly workers at hazardous facilities. Those respondents not closely connected to hazardous facilities (General Commuities, Environmentalists and Science Writers) were distinguished by their concern for everyone, including the contemporary public and future generations. 
The results of this study have significant implications both for our understanding of public perceptions of nuclear power and nuclear waste disposal and for understanding of the ways in which public perceptions should be studied. Nuclear power and nuclear waste disposal were investigated here within the context of all hazardous industrial facilities (as subjectively defined by respondents). Keeping in mind that our sample of respondents was chosen to be representative of selected established groups and commuities, the major findings regarding nuclear power and nuclear waste disposal were:

1. Of all hazardous industrial facilities and types of risk, the most frequently mentioned exposure path was a Leak of Radioactive Material from a Nuclear Power Plant--mentioned twice as frequently as Pollution from General Heavy Industry and three-and-a-half times as frequently as Pollution from a Coal-fired Power Plant.

2. Compared with other industrial facilities, a Nuclear Power Plant was associated nore with pervasive risks, including risks to future generations, rather than risks affecting specific groups of particularly vulnerable persons.

3. Compared with a Toxic Chemical Disposal Facility, a Nuclear Waste Disposal Facility was considered to be more closely associated with leaks of toxic materials affecting everyone, including future generations, the contemporary public and workers at the facility. The hazards of a Toxic Chemical 
Disposal Facility were believed to be confined to the contemporary public.

A Nuclear Power Plant was the facility of greatest concern to our respondents, and it was distinguished by Leaks of Radioactive Materials producing harmful effects for everyone, including future generations. A Nuclear Waste Disposal Facility, obviously not a frequently mentioned hazardous facility since few exist, was also distinguished by similar effects. These results are consistent with national public opinion polls which have found nuclear power to be considered the "most dangerous" source of power (Melber, et al., 1977; 1979). Going beyond the mere perception of danger, the present results indicate the expected mode and targets of exposure: Leaks of Radioactive Material and everyone, including future generations. Slovic and his colleagues (Slovic, Fischhoff and Lichtenstein, 1979; 1980), using samples drawn from the League of Women Voters, college students, businessmen and professional risk assessors, showed that aversion to nuclear power was strongly related to its perceived potential for global catastrophy and threat to future generations. These two items were included in a factor labeled "Common Risk-Dread Risk," the factor Slovic, et al., found to be most predictive of perceived risk. Nuclear power, Slovic, et al. showed, was perceived to be both a dread risk (factor 非 1 ) and an unknown risk ( Eactor 非).

The present results both support those of Slovic, et al., and extend them in several ways. Respondents in Slovic's studies were presented with sets of risk characteristics on which to rate groups of hazards. Respondents in the present study, in contrast, generated their own "risk 
characteristics" within the categories of type of risk and who was affected by it. The primary point of comparison between the two approaches is within the "who is placed at risk" category, where the similarity of results--that globally catastrophic risk and risk to future generations were significant elements in the perceived risk of nuclear power--indicates that at least some of the characteristics used by Slovic, et al, to differentiate among hazards were the same as those spontaneously used by members of the public. Not included among the hazards studied by Slovic, et al., was a Nuclear Waste Disposal Facility. Such a facility was of primary interest here, however, since future developments will depend in substantial degree on public perception and acceptance. Results given here showed that a Nuclear Waste Disposal Facility was perceived similarly to a Nuclear Power Plant in that both were seen to be potentially globally catastrophic and to affect future generations. Thus, while a Nuclear Waste Disposal Facility may be designed and built in order to manage nuclear wastes, such a facility may become the focus of opposition similar to that received by Nuclear Power Plants, and for similar reasons. Finally, the present results extend those of Slovic, et al., to a larger and more heterogeneous sample of respondents.

of general interest to the study of public risk perception was the finding that mention by respondents of concerns for future generations was relatively infrequent across all hazardous industrial facilities. Within the "who is placed at risk" category, references to future generations accounted for only $10.1 \%$ of the total. This result is consistent with the behavior of our contemporary industrial society at 
large, which, according to Meadows, et al., (1972) sustains the present by feeding to it the future. Such an attitude is not surprising; self-preservation certainly takes precedence over concerns for any group of others--particularly a group so distant as to have no voice at all (see Brown and Rankin, 1979).

One of the primary objectives of this study was to relate free response measures of risk perception to the group membership of respondents. Strong and consistent differences among groups were found. Those respondents who were either physically or professionally close to hazardous facilities (Hazardous Facility Commuties, Chemical and Nuclear Engineers) were distinguished from the others by lower levels of concern'about adverse effects, particularly health effects. However, they expressed higher levels of concern for effects to specific groups of living persons, particularly workers at hazardous facilities. These respondents believed that exposure was 1 imited primarily to persons physically or temporally close to the facilities. In contrast, those respondents who were not closely related to hazardous facilities (General Communities, Environmentalists, and Science Writers) were distinguished by higher levels of concern about adverse effects, particularly health effects. This higher level of concern extended to everyone, including the contemporary public and future generations. These respondents believed that exposure was diffuse and extended to persons beyond the immediate physical or temporal bounds of the facilities.

These results, relating physical and professional proximity to hazardous facilities to both the degree and target of respondents' concerns, are consistent with several plausible rival hypotheses. One 
possibility is simple self-selection of respondents. Persons with relatively narrow concerns would be more likely to choose to place themselves physically and professionally close to hazardous facilities. Put otherwise, risk perception "causes" proximity. A second possibility is that economic self interest determines one's concerns; as one's stake in a facility increases, one's concerns about risks produced by that facility narrow. According to this model, proximity "causes" risk perception. A third possibility is that knowledge derived through training or experience determines one's concerns. This model implies that risk perception is affected by physical or professional proximity, but not wholely determined by it. For example, persons neither physically nor professionally close to nuclear power plants could share Nuclear Engineers' views of their risks.

Since this study is not longitudinal, it is not possible to distinguish among these rival hypotheses; the alternative explanations are offered simply to illustrate the limits to interpretation of the results. In all likelihood, one would suspect that concerns about a hazardous facility would be a product of proximity, self-interest, knowledge and perhaps a number of other factors.

This study represents a significant methodological departure from previous practice in the study of risk perception. The items used here were "free response" items which allowed respondents to generate their own response alternatives. In contrast, most studies of risk perception have employed "fixed response" items in which respondents were forced to select from a given set of responses (for a summary of those survey studies that have used free response nuclear power items, see Melber, 
et al., 1979). It can be seen that, under certain circumstances, these two approaches to survey research could produce different, apparently conflicting results. Such apparent conflicts can be resolved, however, through careful consideration of the effects that the research methods themselves have on the results produced. No research result exists independently on its own; all results reside and must be interpreted within the methodological contexts that produced them. Examples from two companion studies of the present one, both of which used fixed response formats, will be used to support this argument.

The first study, reported in Earle et al. (1981), presented data on the relative importance respondents placed on three categories of risk in a multiple-attribute judgment task. Respondents were asked to judge the acceptability of hypothetical radioactive waste management policies based on levels of risk (less, same, or more than the current system) in three categories: Short-term public, Long-term public, and Occupational. Results showed that Occupational risk was less important than the other two categories for all groups of respondents, especially for Chemical and Nuclear Engineers. For most groups, Short-term public was approximately as important as Long-term public. For Environmentalists and Science Writers, however, Long-term public was slightly more important than Shortterm public. The contrast between these results and those produced by the present study is striking. When respondents were asked who was placed at risk by a Nuclear Waste Disposal Facility, $90.6 \%$ of the responses included reference to Short-term public, $30.0 \%$ to Long-term public, and $57.2 \%$ to occupational. The order of importance produced by the free-response format thus was Short-term public, Occupational, and 
Long-term public, in ratios of, roughly, three to two to one. The seeming conflict between the fixed and free-response results is resolved simply by a close examination of the two tasks. In the free-response task, results were based on respondents' response hierarchies. That is, confronted with the task, each respondent possessed a hierarchy of possible responses 1 th descending probabilities of being used. Probability of use is related to the degree of concern the respondent has for various groups of persons. Concern in turn is a function of perceived probability of significant adverse effects. In short, the free-response task produced results based on respondents' concerns about which groups of persons would bear the risks. The fixed-response task, on the other hand, elicited respondents' judgments of equity; that is, respondents made judgments about which group of persons they thought should bear the risk. Respondents indicated that persons in the Occupational category should bear more risk than others, presumably on the basis that workers in a hazardous industry volunteer to expose themselves to risks and are paid to do so.

The second study, reported in Lindell and Earle (1981), included data comparing a Nuclear Waste Disposal Faclity (NWDF) with a Toxic Chemical Disposal Facility (TCDF). Respondents rated those two hazardous facilities (along with six other energy-related facilities) on thirteen riskcharacteristic scales adapted from the work of Slovic and his colleagues (Slovic, Fischhoff and Lichtenstein, 1980). Included in the scales were such characteristics as: Risks known to science ("To what extent are the risks known to science?"); Individual vs. catastrophic risk ("Are the hazards of these facilities likely to kill people one at a time 
[individual risk] or a large number of people at once [catastrophic risk]?"); Personal risk ("To what extent are you personally at risk from the hazards of these facilities?"); and Common vs. dread risk ("Is this a common risk that people have learned to live with and can think about reasonably calmly, or is it one that people have great dread for-on the level of a gut reaction?"). Results showed that respondents did not distinguish between a NWDF and a TCDF in their ratings. Instead, those two facilities along with a Nuclear Power Plant were grouped together as high risk facilities, distinguished from the others by high levels of perceived threat, less well known and less preventable risks, accidents that produce multiple deaths and result in many deaths over time, dread risks and relatively high overall risks which are greater than or equal to the benefits derived from those facilities. In contrast, the free response data indicated that respondents' perceptions of the risks of a NWDF differed markedly from theirs for a TCDF. As was stated in the results section, respondents viewed a TCDF as being more closely associated with Pollution affecting the contemporary public and a NWDF as being more closely associated with Leaks of Radioactive Materials affecting everyone, including future generations, the contemporary public and workers. Again, the apparent conflict between these two sets of results is resolved by a close look at the tasks. As above, the freeresponse results were based on respondents' hierarchies of concerns regarding individual industrial facilities. The fixed-response results, in contrast, were based on respondents' judgments of the characteristics of industrial facilities relative to a given set of other industrial facilities. Thus, considered individually, public concerns regarding a 
NWDF and a TCDF differed in certain respects. Considered relatively, in a specific context, public judgments regarding certain characteristics of a NWDF and a TCDF were the same.

These two sets of contrasts between fixed-and free-response results clearly do not constitute evidence for or against the use of either general approach. The evidence, instead, supports the appropriate use of both approaches. Free-response methods are less directive and more respondent-centered. As such, they may be more appropriately used earlier in the exploration of a content area or in the preliminary sections of a particular study (Lazarsfeld, 1944). Fixed response methods are more directive, more subject to specific methods effects, and should thus be used later in the exploration of a content area or following free-response items in a particular study, taking special care with regard to question wording. Also, since public attitudes and beliefs are in constant flux, the conclusions that we draw from data collected in one time period or in a single context should be tested repeatedly. The study of public risk perception, particularly with regard to the management of radioactive wastes, demands the best in social science research methodology. As Fischhoff, et al,, (1980) have pointed out, "Given the enormous stakes riding on acceptable-risk decisions, our investment in research seems very smal1." The present study has been designed in part to contribute to the development of appropriate public risk perception methodologies. 
REFERENCES

Babbie, E. R. Survey research methods. Belmont, California: Wadsworth, 1973.

Blumer, H. Public opinion and public opinion polling, American Sociological Review, $1948, \underline{13}$ (October), 542-554.

Brown, P. G. and Rankin, W. L. A proxy for the unborn. Bulletin of the Atomic Scientists, $1979,35(9), 64-65$.

Dillman, D. Mail and telephone surveys: The total design method. Somerset, New Jersey: Wiley, 1978.

Earle, T. C., Lindel1, M. K. and Rankin, W. L. Risk perception, risk evaluation and human values concerning nuclear waste management. BHARC(411/81/007), Battelle Human Affairs Research Centers, Seattle, Washington, 1981.

Fischhoff, B., Lichtenstein, S., Slovic, P., Keeney, R. and Derby, S. Approaches to acceptable risk: A critical guide. NUREG/CR-1614. Washington, D. C.: The Commission, 1980.

Glaser, B. G., and Strauss, A. The discovery of grounded theory. Chicago, Illinois: Aldine, 1968 .

Larzarsfeld, P. F. The controversy over detailed interviews-An offer for negotiation. Public Opinion Quarterly, 1944, $8,38-60$.

Lindell, M. K. and Earle, T. C. Comparative Analys is of Risk Characteristics of Nuclear Waste Repositories and Other Disposal Facilities. BHARC(411/81/005), Battelle Human Affairs Research Centers, Seattle, Washington, 1981.

Maynard, W. S., Nealey, S. M., Hebert, J. A. and Lindell, M. K. Public Values Associated with Nuclear Waste Disposal. USERDA Report, BNWL-1997, Battelle Human Affairs Research Centers, Seattle, Washington, 1976.

Meadows, D. H., Meadows, D. L., Randers, J. and Behrens, W. W. The limits to growth. New York: Signet, 1972. 


\section{REFERENCES (COnt.)}

Melber, B. D., Nealey, S. M., Hammersla, J. and Ranikin. W. I. Nuclear power and the public: Analys is of collected survey research. USDOE Report PNL-2430, Battelle Human Affairs Research Centers, Seattle, Washington, 1977.

Melber, B. D., Nealey, S. M., Weiss, C. S. and Rankin, W. L. Nuclear power and the public: Update of collected survey research. (BHARC-411-020). Battelle Human Affairs Research Centers, Seattle, Washington, 1979.

Selltiz, C., Wrightsman, L. S. and Cook, S. W. Research methods in social relations (3rd Edition). New York: Holt, Rinehart and Winston, 1976.

Slovic, P., Fischhoff, B. and Lichtenstein, S. Images of disaster: Perception and acceptance of risks from nuclear power. In G. Goodman and W. Rowe (Eds.), Energy risk management. London: Academic Press, 1979 .

Slovic, P., Fischhoff, B. and Lichtenstein, S. Facts and fears: Understanding perceived risk. In R. Schwing and W. A. Albers, Jr., (Eds.), Societal risk assessment: How safe is safe enough? New York: Plenum, 1980 .

Willer, D. Scientific sociology: Theory and method. Englewood Cliffs, New Jersey: Prentice Hall, 1951. 
No. of

Copies

W. Ballard, Jr.

DOE Office of Energy Programs

Washington, D.C. 20545

D. I. Bodde

Office of Nuclear Policy,

Energy Research

Washington, D.C. 20585

A. A. Churm

DOE Chicago Patent Group

9880 South Cass Avenue

Argonne, IL 60439

27 DOE Technical Information

P.O. Box 62

Oak Ridge, TN 37830

C. H. George

DOE Office of Waste Isolation

Washington, D.C. 20545

G. Graves

Los Alamos Scientific Laboratory

Los Alamos, NM 87544

J. P. Hanric

DOE Idaho Operations Office

550 2nd Street

Idaho Falis, ID 83401

C. A. Heath

DOE Office of Waste Isolation Washington, D.C. 20545

D. Jackson

DOE Office of Public Affairs

Albuquerque Operations Office

Albuquerque, NM 87115

C. Jolly

DOE Office of the Environment

Washington, D.C. 20545
No. of

Copies

\author{
M. J. Lawrence \\ DOE Office of Transportation \\ and Fuel Storage \\ Washington, D.C. 20545
}

R. L. Lowrey

Albuquerque Operations Office Box 5400

Albuquerque, NM 87115

\section{J. B. Martin}

NRC Division of Fuel Cycle and Material Safety

Washington, D.C. 20555

E. F. Mastal

DOE Office of Resource

Management and Planning

Washington, D.C. 20545

D. F. Miller

DOE Office of Public Affairs

Nevada Operations office

Las Vegas, NV 89114

R. L. Murray

Nuclear Engineering

Department

North Carolina State

University

Raleigh, NC 27650

J. O. Neff

DOE National Waste Terminal Storage Program office

505 King Avenue

Columbus, $\mathrm{OH} \quad 43201$

G. K. Dertel

DOE Office of Waste Operations and Technology Washington, D.C. 20545 


\section{DISTRIBUTION (Cont.)}

No. of

Copies

A. F. Perge

DOE Office of the Deputy

Ass istant Secretary for

Nuclear Waste Management

Washington, D.C. 20545

J. Pomeroy

National Academy of Sciences

Washington, D.C. 20518

\section{R. W. Ramsey}

DOE Projects Staff

Washington, D.C. 20545

L. J. Snith

TRU Waste Systems Office Rocky Flats Plant

Golden, CO 80401

S. L. Topp

Savannah River Laboratory

Aiken, SC 29801

V. G. Trice

DOE Office of Resource

Management and $\mathrm{Planning}$

Washington, D.C. 20545

E. J. Wahlquist

DOE Office of Resource

Management and Planning

Washington, D.C. 20545
No. of

Copies

Pacific Northwest Laboratory

5 Technical Files

2 Publishing Coordination

J. B. Burnham

T. D. Chikalla

D. E. Deonigi

M. R. Kreiter

J. M. Latkovich

R. P. Marshall

D. E. Olesen

A. M. Platt

5 J. V. Robinson

Richland Operations office

3 Contract office

T. A. Bauman

P. A. Craig

R. B. Goranson

R. W. Newl in

H. E. Ransom

J. J. Schreiber

M. W. Shupe

F. R. Standerfer

Office of Nuclear Waste Isolation
N. Carter
J. Finley
S. Goldsmith
M. Kehnemuyi
D. Keller
J. Mountain
B. Rawles
J. Marriott 